\title{
Effects of temperature and food availability on feeding and egg production of Calanus hyperboreus from Disko Bay, western Greenland
}

\author{
Marie Vestergaard Henriksen ${ }^{1}$, Signe Jung-Madsen ${ }^{1}$, Torkel Gissel Nielsen ${ }^{2,3, *}$, \\ Eva Friis Møller ${ }^{1}$, Karen Vestergaard Henriksen ${ }^{1}$, Stiig Markager ${ }^{1}$, \\ Benni Winding Hansen ${ }^{4}$ \\ ${ }^{1}$ Department of Bioscience, Aarhus University, Frederiksborgvej 399, 4000 Roskilde, Denmark \\ ${ }^{2}$ National Institute of Aquatic Resources, DTU Aqua, Section for Ocean Ecology and Climate, \\ Technical University of Denmark, Kavalergården 6, 2920 Charlottenlund, Denmark \\ ${ }^{3}$ Greenland Climate Research Centre, Greenland Institute of Natural Resources, PO Box 570, 3900 Nuuk, Greenland \\ ${ }^{4}$ Department of Environmental, Social and Spatial Change, Roskilde University, Roskilde, Denmark
}

\begin{abstract}
The effects of temperature and food availability on feeding and egg production of the Arctic copepod Calanus hyperboreus were investigated in Disko Bay, western Greenland, from winter to spring 2009. The abundance of females in the near bottom layer and the egg production of $C$. hyperboreus prior to the spring bloom document that reproduction relies on lipid stores. The maximum in situ egg production $\left( \pm \mathrm{SE}\right.$ ) of $54 \pm 8$ eggs female $\mathrm{e}^{-1} \mathrm{~d}^{-1}$ was recorded in mid-February at chlorophyll a concentrations below $0.1 \mathrm{\mu g} \mathrm{l}^{-1}$, whereas no egg production was observed in midApril when the spring bloom developed. After reproduction, the females migrated to the surface layer to exploit the bloom and refill their lipid stores. In 2 laboratory experiments, initiated before and during the spring bloom, mature females were kept with and without food at 5 different temperatures ranging from 0 to $10^{\circ} \mathrm{C}$ and the fecal pellet and egg production were monitored. Food had a clear effect on fecal pellet production but no effect on egg production, while temperature did not have an effect on egg or fecal pellet production in any of the experiments. Analyses of carbon and lipid content of the females before and after the experiments did not reflect any effect of food or temperature in the pre-bloom experiment, whereas in the bloom experiment a clear positive effect of food was detected in female biochemical profiles. The lack of a temperature response suggests a future warmer ocean could be unfavorable for $C$. hyperboreus compared to smaller Calanus spp. which are reported to exploit minor temperature elevations for increased egg production.
\end{abstract}

KEY WORDS: Calanus hyperboreus - Egg production - Fecal pellet production - Effect of temperature Resale or republication not permitted without written consent of the publisher

\section{INTRODUCTION}

The annual productivity cycle in arctic ecosystems is greatly influenced by interannual variations in sea ice cover and solar irradiance as the breakup of the sea ice increases available light to the surface water in the spring. In Disko Bay, western Greenland, the breakup of the sea ice varies greatly between years (Nielsen \& Hansen 1995, S.D. Madsen et al. 2001, 2008, Hansen et al. 2006, S.J. Madsen et al. 2008, Dünweber et al. 2010). However, a general increase in mean air temperature of $0.4^{\circ} \mathrm{C} \mathrm{yr}^{-1}$ and a reduction 
in sea ice cover of $50 \%$ were observed from 1991 to 2004 (Hansen et al. 2006). This makes Disko Bay an ideal site for investigating the impact of climatechange-mediated variation in the ice cover on succession patterns in pelagic food webs.

Calanus hyperboreus, C. glacialis, and C. finmarchicus are key species in arctic marine food webs. With their ability to convert phytoplankton to highenergy wax esters, they provide a high-quality food source for fish, seabirds, and marine mammals (Heide-Jørgensen \& Acquarone 2002, Karnovsky et al. 2003, Falk-Petersen et al. 2009). All 3 Calanus species are adapted to arctic conditions by having life cycles with seasonal ontogenetic migration and accumulation of lipids during spring and summer, as well as hibernation and arrested development during winter (Conover 1988, Madsen et al. 2001). C. glacialis and C. hyperboreus are true Arctic species, whereas $C$. finmarchicus have their main distribution in the Atlantic (Conover 1988). However, in Disko Bay, all 3 co-exist (Madsen et al. 2001).

In early spring, when the breakup of the sea ice triggers the formation of the spring bloom (Dünweber et al. 2010), Calanus spp. ascend from deep waters (Madsen et al. 2001) and start feeding to support egg production and to refuel lipid reserves (Madsen et al. 2001, Swalethorp et al. 2011). When the bloom has ceased and the Calanus species have refilled their lipid stores, they stop eating and descend to the near-bottom layers where they slow down their metabolism and over-winter in a state of diapause (Lee et al. 2006).

Calanus hyperboreus differ from C. glacialis and C. finmarchicus in a number of traits, particularly lifecycle and reproductive strategies. C. hyperboreus have the longest life span of the 3 species, living typically between 2 and 5 yr (Scott et al. 2000, Madsen et al. 2001). In contrast to the 2 others, C. hyperboreus do not produce eggs after their ascent. They complete spawning during winter in the deep waters using their lipid stores to fuel egg production, and their eggs ascend to the photic zone (Hirche \& Niehoff 1996, Melle \& Skjoldal 1998). Winter spawning gives $C$. hyperboreus an advantage since the eggs have developed to the first feeding nauplii stage at the onset of the bloom. This enables nauplii of C. hyperboreus to undergo more developmental stages during the productive season and to better exploit even a short-lasting bloom. C. hyperboreus accumulate lipids more effectively than the 2 other Calanus species (Pasternak et al. 2001, Søreide et al. 2008) and can therefore descend to deeper waters earlier, sometime between June and August (Mad- sen et al. 2001). Furthermore, the large lipid reserves increase the ability of $C$. hyperboreus to arrest development and thereby survive in areas with high variability in ice cover (Scott et al. 2000), e.g. the Disko Bay area.

The air temperatures in the Arctic have been predicted to increase by 4 to $7^{\circ} \mathrm{C}$ over the next $100 \mathrm{yr}$ (ACIA 2004). Increasing temperatures reduce sea ice coverage and thickness. Furthermore, a warmer climate will increase meltwater runoff to the sea, and in combination, these factors can be expected to lead to an earlier stabilization of the water column and as a consequence earlier onset of the arctic spring bloom (Hansen et al. 2003). In Disko Bay, noteworthy hydrographic changes have occurred during the last decades (Hansen et al. in press). The duration of ice cover has decreased by approximately $50 \%$ (Hansen et al. 2006), and the date of ice break, and the subsequent spring bloom, now occurs earlier. In addition, there has been an acceleration in meltwater input from the Jakobshavn glacier to the bay due to increased submarine melting as a result of the increased presence of warmer oceanic waters from the Atlantic in the bay (Holland et al. 2008, Motyka et al. 2011).

An increase in temperature will not only prolong the productive season of the phytoplankton and the production of the Calanus community but may also impact the relative composition of the Calanus biomass. Kjellerup et al. (2012, this volume) showed a significant effect of temperature on egg production and feeding of C. finmarchicus and C. glacialis, including evidence that $C$. finmarchicus have a stronger positive response to increasing temperatures than $C$. glacialis. These results are supported by the models of Slagstad et al. (2011), which demonstrated that C. finmarchicus will take over the northern Barents Sea at the expense of C. glacialis in a warmer future. Several studies of temperature effects on production of arctic copepods have been conducted. Among these, the relationship between temperature, food concentration, and reproduction has been established for C. finmarchicus and C. glacialis (Hirche \& Kwasniewski 1997, S.J. Madsen et al. 2008, Kjellerup et al. 2012). However, information on the effects of temperature on the functional biology of C. hyperboreus is limited (Hirche 1987, Plourde et al. 2003).

The aim of the present study was therefore to investigate the effects of temperature and food availability on feeding and egg production of Calanus hyperboreus in Disko Bay before and during the phytoplankton spring bloom. In parallel, bloom dynamics and in situ egg production of C. hyperboreus were followed in Disko Bay. 


\section{MATERIALS AND METHODS}

\section{Study site}

Sampling was conducted from 10 February to 25 May 2009 about 1 nautical mile off the coast of Qeqertarsuaq in Disko Bay, western Greenland $\left(69^{\circ} 15^{\prime} \mathrm{N}, 53^{\circ} 33^{\prime} \mathrm{W}\right.$, Fig. 1) The station is 250 to $300 \mathrm{~m}$ deep and was previously used in studies of the pelagic community of the bay (Nielsen \& Hansen 1995, Madsen et al. 2001, S.J. Madsen et al. 2008, Dünweber et al. 2010). Sampling on 10 February and from 17 April to 25 May was carried out from a research vessel. On all other sampling dates, samples were taken through a hole made in the sea ice.

\section{Hydrography and phytoplankton}

Temperature and salinity in the water column were measured using a Seabird SBE25-01 CTD, and water samples from 1, 20, 50, 75, 100, 150, 200, and $250 \mathrm{~m}$ were taken with a 301 Niskin water bottle. Water samples were kept cold and dark in 101 plastic containers and transported back to the laboratory. Here, $500 \mathrm{ml}$ triplicates from each depth were filtered onto GF/F filters and extracted overnight in $5 \mathrm{ml} \mathrm{96 \%}$ ethanol (Jespersen \& Christoffersen 1987) and fluorescence was measured on a Turner Design Model 700 fluorometer before and after acid addition. Salinity measurements were calibrated against salinity samples taken approximately once a month $(\mathrm{n}=4)$ throughout the study phase, and analyzed on an 8410-Portasal salinometer (Guildline).

\section{Depth distribution of Calanus hyperboreus}

Female Calanus hyperboreus were sampled on 10 February and 17 April in $50 \mathrm{~m}$ depth intervals $(n=5)$ from $250 \mathrm{~m}$ to the surface. This was done using a Hydrobios Multinet (type Midi, opening $0.25 \mathrm{~m}^{2}$ ) with nets of $50 \mu \mathrm{m}$ in mesh size. The samples were immediately preserved in buffered formalin ( $2 \%$ final concentration), and in the laboratory we quantified the proportion of mature females ready to spawn (i.e. with visible orange gonads, stage GS4 according to Niehoff \& Hirche 1996, Niehoff \& Runge 2003).

\section{In situ egg production}

Calanus hyperboreus females were sampled from the bottom to the surface using a WP-2 net $(200 \mu \mathrm{m})$ equipped with a large non-filtering cod end. The samples were diluted and stored in a thermobox. In the laboratory, mature females (GS4 sensu Niehoff \& Hirche 1996, Niehoff \& Runge 2003; 13 to 20 replicates) were sorted out and placed individually in $600 \mathrm{ml}$ polycarbonate bottles filled with $45 \mu \mathrm{m}$ screened surface water. The bottles were incubated at $5^{\circ} \mathrm{C}$ for $48 \mathrm{~h}$, after which the content of each bottle was concentrated on a $45 \mu \mathrm{m}$ filter. The eggs were counted and the prosome length of the females measured. All eggs spawned within the $48 \mathrm{~h}$ were considered to belong to the same clutch (spawning interval at $4.5^{\circ} \mathrm{C}$ for C. hyperboreus is $5.6 \mathrm{~d}$, Plourde et al. 2003). As only mature females with visible welldeveloped gonads (GS4) were incubated, the egg production (EP) rate measured would overestimate population EP. Therefore, EP rates were corrected for maturity of the female population by multiplying the observed EP by the proportion of mature females in the population based on the biomass samples (see Fig. 5a, Table 3). As carbon content of the females decreased by more than $50 \%$ over the period investigated, none of the previously established lengthweight regressions could be used to estimate carbon content of females. An exponential decrease in dry weight (DW) over the spring has been demonstrated for C. hyperboreus (Conover \& Siferd 1993). Therefore, average carbon content of females was esti-
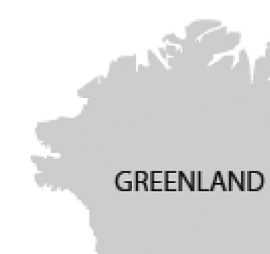

EENLAND

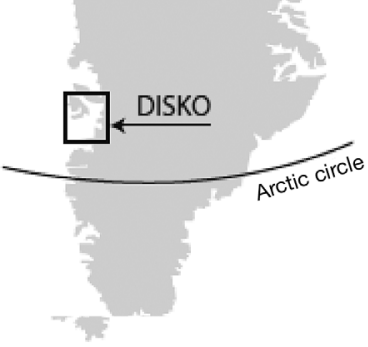

Fig. 1. Study site in Disko Bay, western Greenland

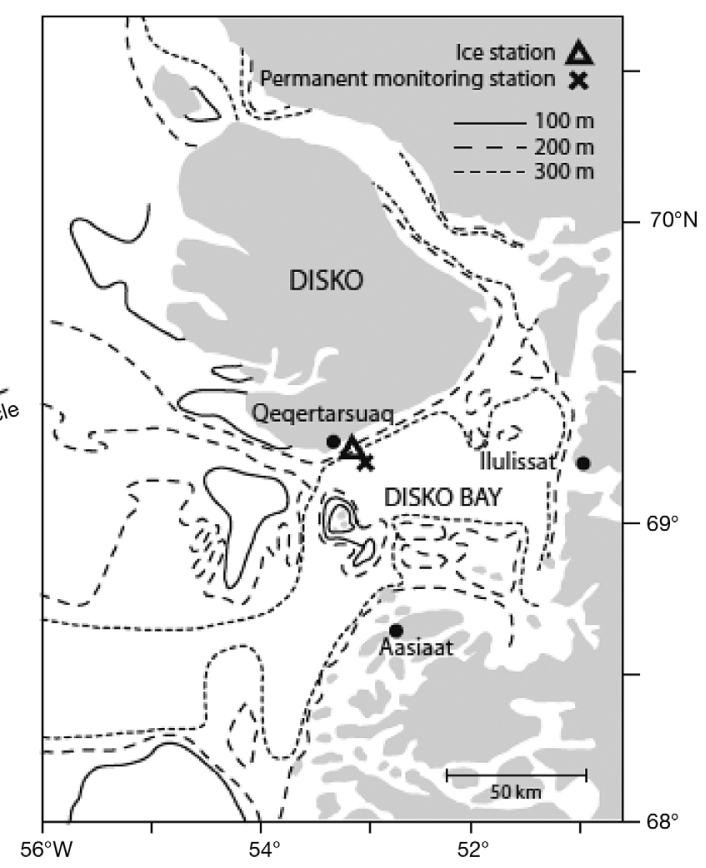


mated for each date using an exponential regression between in situ carbon content of females collected on 10 February and 17 April (see Table 4). Eggs from females sampled on 10 February were collected and immediately measured, and a mean egg volume was calculated assuming a spherical shape. The carbon content of eggs was calculated using a volume to carbon conversion factor for C. glacialis and C. finmarchicus of $1.10 \times 10^{-7} \mu \mathrm{g} \mathrm{C} \mathrm{\mu m}^{-3}$ (Swalethorp et al. 2011). The carbon contents of females and eggs were then used to calculate specific EP (SEP). To estimate average total fecundity of females, an exponential regression was fitted to the observed EP. Using this regression, a new daily EP was estimated and summed over the period of investigation.

\section{Laboratory experiment}

The laboratory experiment was conducted twice, each time over a $2 \mathrm{wk}$ period. The first experiment was set up on 10 February, before the spring bloom, and the second on 17 April, during the spring bloom. Females used in the experiments were collected in the same manner as for the in situ EP experiment, and kept on ice during handling.

\section{Setup}

Within $3 \mathrm{~h}$ after the mature females (GS4) were sampled, they were carefully sorted out and incubated at 5 different temperatures: $0,2.5,5,7.5$, and $10^{\circ} \mathrm{C}$. Before starting each experiment, the copepods were acclimated to the temperature for 3 to $6 \mathrm{~d}$, and individuals that were fed later, during the experiment, were acclimated to food concentration for $3 \mathrm{~d}$. Thirty females were used at each temperature, half of which were kept starved in $0.2 \mu \mathrm{m}$ filtered sea water and the other half kept under saturated food conditions in $0.2 \mu \mathrm{m}$ filtered sea water with $15 \mu \mathrm{g}$ chlorophyll (chl) $a$ $\mathrm{l}^{-1}$ of the diatom Thalassiosira weissflogii (equal to $680 \mu \mathrm{g} \mathrm{C} \mathrm{1}{ }^{-1}$; Reigstad et al. 2005). Cultures of $T$. weissflogii were grown in a 12:12 light:dark cycle (2 Osram L, 36 W/840, Lumilux cool white placed $40 \mathrm{~cm}$ away) in $0.2 \mu \mathrm{m}$ filtered seawater at room temperature, and $B_{1}$ medium (1 ml $\mathrm{l}^{-1}$ ) (Hansen 1989), silicate $\left(0.9 \mathrm{ml} \mathrm{l}^{-1}\right)$, and vitamins $\left(0.5 \mathrm{ml} \mathrm{l}^{-1}\right)$ were added every other day. The cultures were renewed every 1 to $2 \mathrm{wk}$ and were constantly aerated.

Five thermo boxes filled with freshwater were used to keep the temperatures constant. Hobo thermo loggers were used throughout the experiment to log the
Table 1. Temperature in laboratory experiments

\begin{tabular}{|lrr|}
\hline \multirow{2}{*}{$\begin{array}{l}\text { Intended } \\
\text { temperature }\left({ }^{\circ} \mathrm{C}\right)\end{array}$} & $\begin{array}{r}\text { Measured temperature } \pm \mathrm{SD}\left({ }^{\circ} \mathrm{C}\right) \\
\text { Pre-bloom }\end{array}$ & \multicolumn{1}{c|}{ Bloom } \\
\hline 0 & $0.5 \pm 0.7$ & $0.7 \pm 1.3$ \\
2.5 & $2.6 \pm 0.3$ & $2.7 \pm 0.2$ \\
5 & $5.1 \pm 1.0$ & $5.8 \pm 0.8$ \\
7.5 & $7.3 \pm 0.7$ & $7.5 \pm 0.4$ \\
10 & $10.0 \pm 0.4$ & $10.1 \pm 0.5$ \\
\hline
\end{tabular}

temperature every $15 \mathrm{~min}$ (Table 1 ). In each thermobox, 2 buckets (10 l each) filled with 8.31 filtered sea water $(0.2 \mu \mathrm{m})$ were placed, and Thalassiosira weissflogii was added to one of these. In each bucket, 15 female Calanus hyperboreus were contained in a cylinder with false bottom (400 $\mu \mathrm{m}$ mesh). Every day the cylinders were carefully transferred to new buckets with 2.51 filtered water at the corresponding temperature. The water from the old buckets was filtered with a $45 \mu \mathrm{m}$ filter by reverse filtration, and the concentrated samples were collected and preserved in Lugol's solution ( $2 \%$ final concentration). Finally, 5.81 of this filtered water were transferred to the new buckets and phytoplankton culture was added to adjust food concentration for the fed females. The eggs and pellets collected in the experiment were counted daily. Length and width of approximately 30 pellets from every temperature, both starved and fed, were measured on Days 2, 7, and 14 for both experiments in order to calculate an average fecal pellet volume. Only pellets with length at least 3 times their width were counted and measured.

Mortality in the 2 experiments averaged $1 \% \mathrm{~d}^{-1}$. During the experiment, dead females were removed, their prosome length measured, and subsequently replaced with new individuals previously starved and kept at $5^{\circ} \mathrm{C}$. The females were acclimated to the proper temperature for approximately half a day before being added to the buckets. At the end of both experiments, prosome length of every individual was measured and a mean female length in each treatment was calculated.

\section{Fecal pellet production as a proxy for grazing}

All fecal pellet measurements from the starved treatments were corrected for shrinkage due to fixation in Lugol's solution, as this reduces the volume of pellets from starved individuals by $21 \%$ (Kjellerup et al. 2012). Fecal pellet volumes for the fed and starved treatments in each experiment were then calculated 
Table 2. Calanus hyperboreus. Mean \pm SD fecal pellet volume $\left(10^{5} \mu^{3}\right)$ for fed and starved females in each experiment

\begin{tabular}{|lccccc|}
\hline & \multicolumn{2}{c}{ Pre-bloom } & & \multicolumn{2}{c|}{ Bloom -} \\
\cline { 6 - 6 } & $\mathrm{n}$ & Pellet volume & & $\mathrm{n}$ & Pellet volume \\
\hline Fed & 460 & $48.1 \pm 23.7$ & & 456 & $32.9 \pm 13.0$ \\
Starved & 425 & $36.6 \pm 20.7$ & & 174 & $12.3 \pm 6.5$ \\
\hline
\end{tabular}

from the length and width of pellets assuming that they were of a cylindrical shape. As no significant effect of temperature on pellet volume was detected, a mean volume for fed or starved females was calculated (Table 2). From these values, the carbon content was calculated using a conversion factor of $8.03 \times 10^{-8}$ $\mu \mathrm{g} \mathrm{C} \mu \mathrm{m}^{-3}$ (Reigstad et al. 2005) for the fed treatment and $4.75 \times 10^{-8} \mu \mathrm{g} \mathrm{C} \mathrm{mm}^{-3}$ (Seuthe et al. 2007) for the starved treatment. These factors were measured in experiments with food concentrations comparable to this experiment using Calanus finmarchicus and $C$. glacialis. The carbon contents of females and fecal pellets were then used to calculate a cumulative carbon specific fecal pellet production $\left(\mathrm{SPP}_{\text {cum }}\right)$ for each treatment in each experiment (see Fig. 6).

\section{Egg production}

Together with the female carbon content, the mean carbon content of eggs (estimated as described for the in situ EP) was used to calculate the cumulative specific egg production $\left(\mathrm{SEP}_{\text {cum }}\right)$ for each treatment in each experiment (see Fig. 6).

\section{Carbon measurements}

Before each experiment, 24 of the females collected in the field were washed in filtered seawater $(0.2 \mu \mathrm{m})$, their prosome length was measured, and they were placed in pre-weighed tin capsules. They were then dried for $24 \mathrm{~h}$ at $60^{\circ} \mathrm{C}$ and stored frozen $\left(-30^{\circ} \mathrm{C}\right)$ for 8 to $10 \mathrm{mo}$. After re-drying the samples, the carbon content of each individual was measured on a CHNS Automatic Elemental Analyzer (EA 1110 CHNS, CE Instruments). This procedure was later repeated on approximately 7 females from each treatment after the experiments had ended. The carbon content was used to make a linear interpolation between the initial weight and the weight on the last day of each treatment for both experiments. These relationships were then used to estimate the carbon weight of females for each day of the experiments and subsequently to calculate daily carbon specific egg and pellet production (SEP and SPP).

\section{Lipid measurements}

Approximately 20 females before the experiments and 5 females from each treatment after the experiments were placed individually in lipid test tubes with a Teflon cap. One ml chloroform:methanol solution (2:1 by volume) was added, and the samples were stored at $-30^{\circ} \mathrm{C}$ for 2 to $4 \mathrm{mo}$ and then at $-80^{\circ} \mathrm{C}$ for $7 \mathrm{mo}$. Before analyses, an additional $2 \mathrm{ml}$ chloroform:methanol solution was added. For a more detailed description, see Swalethorp et al. (2011).

\section{Data analysis}

The effects of temperature and food availability were tested with a general linear model (GLM, SAS Version 9.1) where the response ( $y$ ) equals:

$$
y=\text { intercept }+\left(k_{\text {food }} \times \text { food }\right)+\left(k_{\text {temp }} \times \text { temp }\right)
$$

The model describes change in either SPP, SEP, carbon, nitrogen, or lipid content over the incubation period, where temp is the temperature in the experiment and food is a variable that has a value of 0 for starved females and 1 for fed females. On a few occasions (e.g. Eq. 5), the time of the year was included by adding a third term $\left(k_{\text {season }} \times\right.$ season $)$, where the variable season has a value of 0 in the pre-bloom experiment and a value of 1 in the bloom experiment. The coefficients $k_{\text {food, }} k_{\text {temp }}$ and $k_{\text {season }}$ quantify the effects of temperature, food and season, respectively. During analysis of lipid content, the values for triacylglycerol (TAG) at $10^{\circ} \mathrm{C}$ were not included in the model, as they were unrealistically high and therefore considered as outliers (see Table 7).

$\mathrm{SPP}_{\text {rate }}$ and $\mathrm{SEP}_{\text {rate }}$ were estimated as the slopes in a 2-phase model using an iterative non-linear SAS procedure for each of the 10 different treatments to estimate the coefficients that best explained the observed rates for $\mathrm{SPP}_{\text {cum }}$ and $\mathrm{SEP}_{\text {cum. }}$. A visual inspection of the time course (see Fig. 6) clearly showed that the cumulative production increased linearly with time but also that a shift in the rate of production, both upward and downward, occurred during many of the experiments. In order to model this variability, a 2-phase model was constructed:

$$
\begin{aligned}
& \text { if day } \leq 1 \text { then } p=\text { day } \times k_{1} \\
& \text { if day }>1 \text { then } p=k_{1} \times 1+k_{2} \times(\text { day }-1)
\end{aligned}
$$




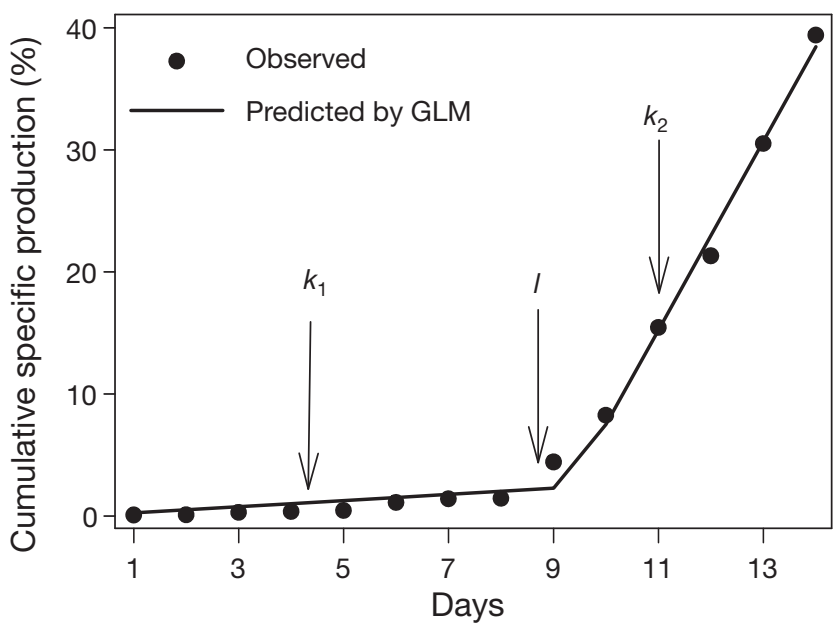

Fig. 2. Model used to establish specific fecal pellet production rate $\left(\mathrm{SPP}_{\text {rate }}\right)$ and specific egg production rate $\left(\mathrm{SEP}_{\text {rate }}\right)$ from the cumulative production. $k_{1}$ : slope of the line $\left(\% \mathrm{C} \mathrm{d}^{-1}\right)$ from Day 1 to $l$ (the intercept between the fitted lines); $k_{2}$ : slope of the line $\left(\% \mathrm{C} \mathrm{d}^{-1}\right)$ from $l$ to Day 14

where $p$ is the cumulative production of pellets or eggs, $k_{1}$ and $k_{2}$ are the coefficients for the daily production, and $l$ is the time where the shift from $k_{1}$ to $k_{2}$ occurs (Fig. 2). To avoid $k_{1}$ or $k_{2}$ being determined based on $<3$ data points, bounds where placed on 1 so that $3 \leq 1 \leq 13$. Tests were performed with a free estimate of $l$ and with a constant value of $l=6$, and they showed only minor deviations in the estimates of $k_{1}$ and $k_{2}$. The parameters were estimated with SAS proc NLIN. Temperature coefficients for changes in $k_{1}$ and $k_{2}$ with temperature were estimated using a simple linear model followed by a $t$-test of the coefficient relative to 0 . Carbon-specific values are given in \% for SPP and SEP or as \% $\mathrm{d}^{-1}$ for $\mathrm{SPP}_{\text {rate }}$ and $\mathrm{SEP}_{\text {rate }}\left(\mu \mathrm{g} \mathrm{C}_{\text {egg }} \mu \mathrm{g} \mathrm{C}_{\text {female }}{ }^{-1} \mathrm{~d}^{-1} \times 100\right)$. Unless otherwise noted, all reported means are given $\pm \mathrm{SE}$.

\section{Energy budget for females}

An energy budget was established following Auel et al. (2003) for the 2 experiments and for in situ development of EP, using the observed differences in total lipid content between the beginning and the end of the experiments, the number of eggs spawned, the lipid content of Calanus hyperboreus eggs $\left(0.54 \pm 0.01 \mu\right.$, i.e $5.4 \times 10^{-4} \mathrm{mg} \mathrm{egg}^{-1}$; S. JungMadsen et al. unpubl.), an energy content of lipids of $42.7 \mathrm{~J} \mathrm{mg}^{-1}$ (Conover 1964, Båmstedt 1986), and $\mathrm{a}$ respiration rate of females of $0.26 \mathrm{ml} \mathrm{O}_{2} \mathrm{~g}^{-1} \mathrm{DW} \mathrm{h}^{-1}$ (Auel et al. 2003) converted to $10.4 \mathrm{ml} \mathrm{O}_{2} \mathrm{~g}^{-1} \mathrm{C} \mathrm{d}^{-1}$ (assuming a carbon content of $60 \%$ of dry weight;
Omori 1969, Plourde et al. 2003). Finally, to convert respiration into daily energy requirements, an oxycaloric equivalent of $19.64 \mathrm{~J} \mathrm{ml}^{-1} \mathrm{O}_{2}$ was assumed as typical for lipid-based metabolism (Ikeda et al. 2000). The energy budget for in situ EP was calculated by multiplying average female fecundity over the season (66 d) by lipid content of eggs and comparing it with the loss of female lipids occurring in the same period. Potential in situ EP (eggs female ${ }^{-1} \mathrm{~d}^{-1}$ ) was calculated as:

$$
\begin{aligned}
& \mathrm{EP}_{\text {potential }}= \\
& \frac{\left(\mathrm{TL}_{\text {loss }} \times 42.7-10.4 \times \mathrm{C}_{\text {females }} \times 19.64 \times 66\right) / 42.7}{5.4 \times 10^{-4}}
\end{aligned}
$$

where $\mathrm{TL}_{\text {loss }}=$ loss of total lipids $(\mathrm{mg})$ and $\mathrm{C}_{\text {females }}=$ average carbon content of females ( $g$ ) during the period. $\mathrm{C}_{\text {females }}$ was estimated by averaging the carbon content of females calculated for each day over the period of $66 \mathrm{~d}$ assuming an exponential relationship between measurements on 10 February and 17 April.

\section{RESULTS}

\section{Hydrography and phytoplankton}

In February there was a clear pycnocline just below $100 \mathrm{~m}$. The temperature increased from about $-1.6^{\circ} \mathrm{C}$ in the surface layers to $3^{\circ} \mathrm{C}$ in the bottom layers, and salinity increased from 32.9 in the surface to 34.2 at $250 \mathrm{~m}$ (Fig. 3A). The chl a concentration was very low throughout the water column, with values increasing toward the surface and reaching a maximum concentration at $0.05 \mu \mathrm{g} \mathrm{l}^{-1}$ at $20 \mathrm{~m}$. Due to malfunction of the CTD, no CTD cast from April can be presented. Instead, Fig. 3B shows point measurements of temperature, salinity, and chl a made at 8 depths. In April, a weak pycnocline at about $50 \mathrm{~m}$ was present, but the main pycnocline was still situated just below $100 \mathrm{~m}$. As in February, the temperature at the bottom was around $3^{\circ} \mathrm{C}$. Chl a was found from the surface and down to $150 \mathrm{~m}$, showing that the phytoplankton spring bloom was well underway. Highest chl a concentrations were found above $50 \mathrm{~m}$, peaking at $1.6 \mu \mathrm{g} \mathrm{l^{-1 }}$ at $1 \mathrm{~m}$.

\section{Depth distribution of Calanus hyperboreus}

From February to mid-April, the majority of females were found in the deepest strata (Fig. 4) at 


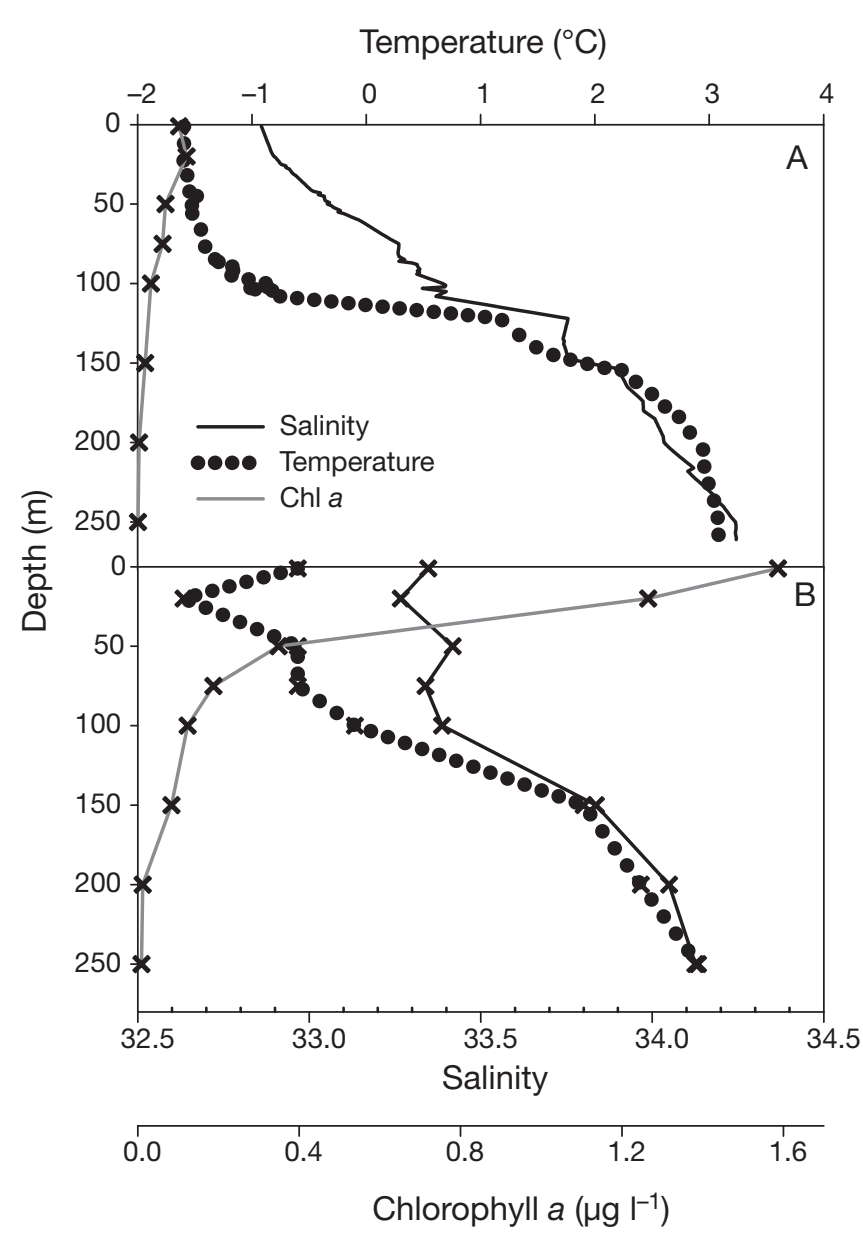

Fig. 3. Hydrography of Disko Bay on (A) 10 February and (B) 17 April 2009, showing salinity, temperature and chlorophyll concentration. (A) CTD data of salinity and temperature and point measurements of chl a. (B) Point measurements of all parameters at 8 depths (crosses) due to malfunction of CTD on 17 April

constant positive temperatures $\left(3^{\circ} \mathrm{C}\right)$ and very low food concentration. At the beginning of the second experiment on 17 April, $10 \%$ of the females were found in the surface waters, indicating that the ascent towards the surface had just begun. By late April, the majority of females had ascended to surface waters.

\section{In situ egg production}

The proportion of ripe females and in situ EP were measured between 10 February and 17 April. Egg diameter was $198 \pm 7 \mu \mathrm{m}$, giving an egg volume of $40.8( \pm 5) \times 10^{5} \mu^{3}(\mathrm{n}=110$, mean $\pm \mathrm{SD})$. The measurements of in situ EP showed that EP was inversely correlated with the chl a concentration of the water

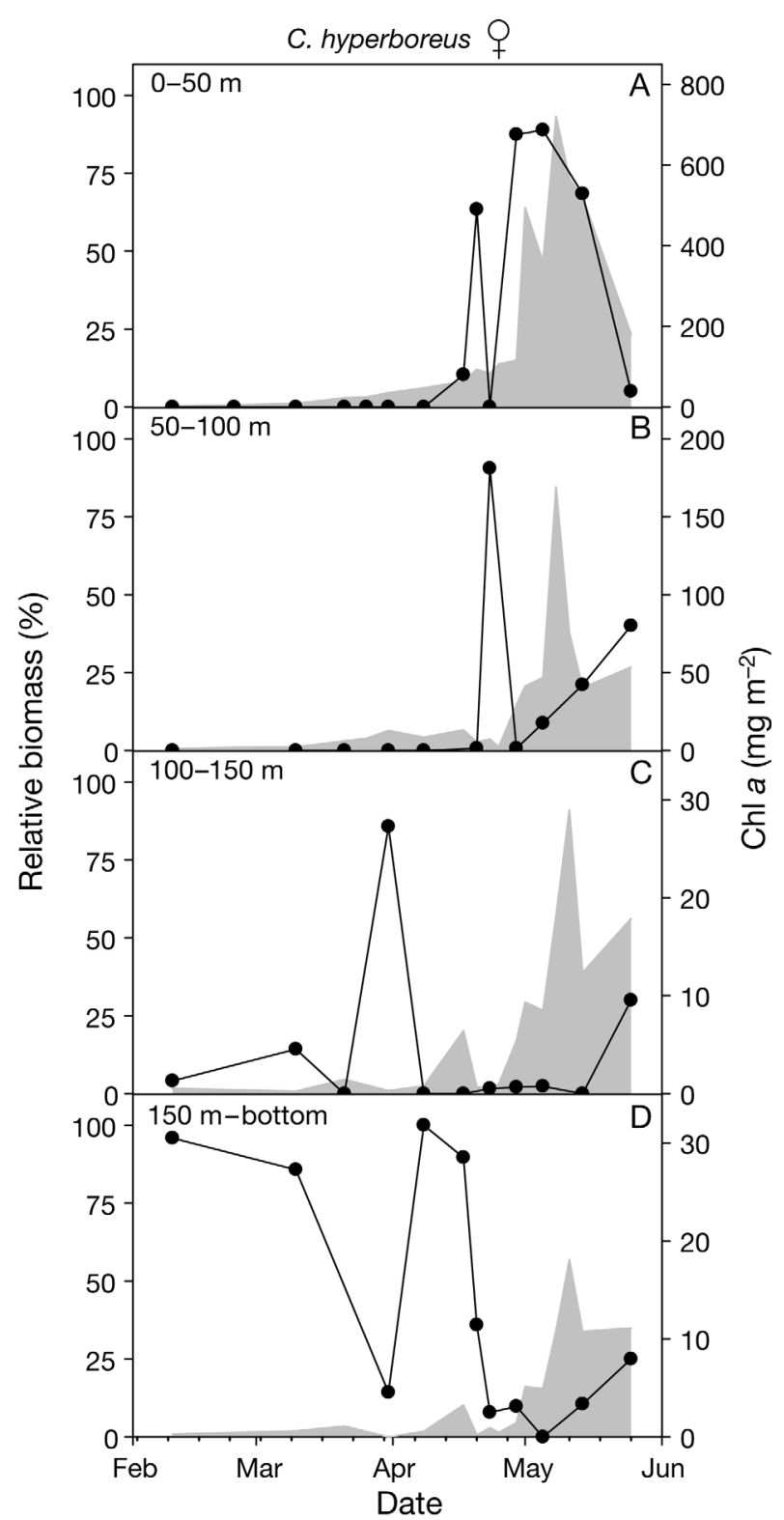

Fig. 4. Calanus hyperboreus. Relative depth distribution of females (left $y$-axis) and integrated chlorophyll (chl) a (shaded area; right $y$-axis: note different scale) in the different depths from 10 February to 25 May

(Fig. 5). Mean population EP was $54 \pm 8$ eggs female ${ }^{-1} \mathrm{~d}^{-1}$ before the spring bloom and ceased as the proportion of ripe females declined, until 17 April at the beginning of the spring bloom when spawning was terminated (Fig. 5, Table 3). Clutch size was quite variable, ranging between 9 and 416 eggs clutch $^{-1}$. During the main spawning event (February to March), average clutch size ranged between $107 \pm$ 19 and $165 \pm 52$ eggs, whereas in early April when EP had ceased, clutch size averaged $30 \pm 5$ eggs (Table 3). 


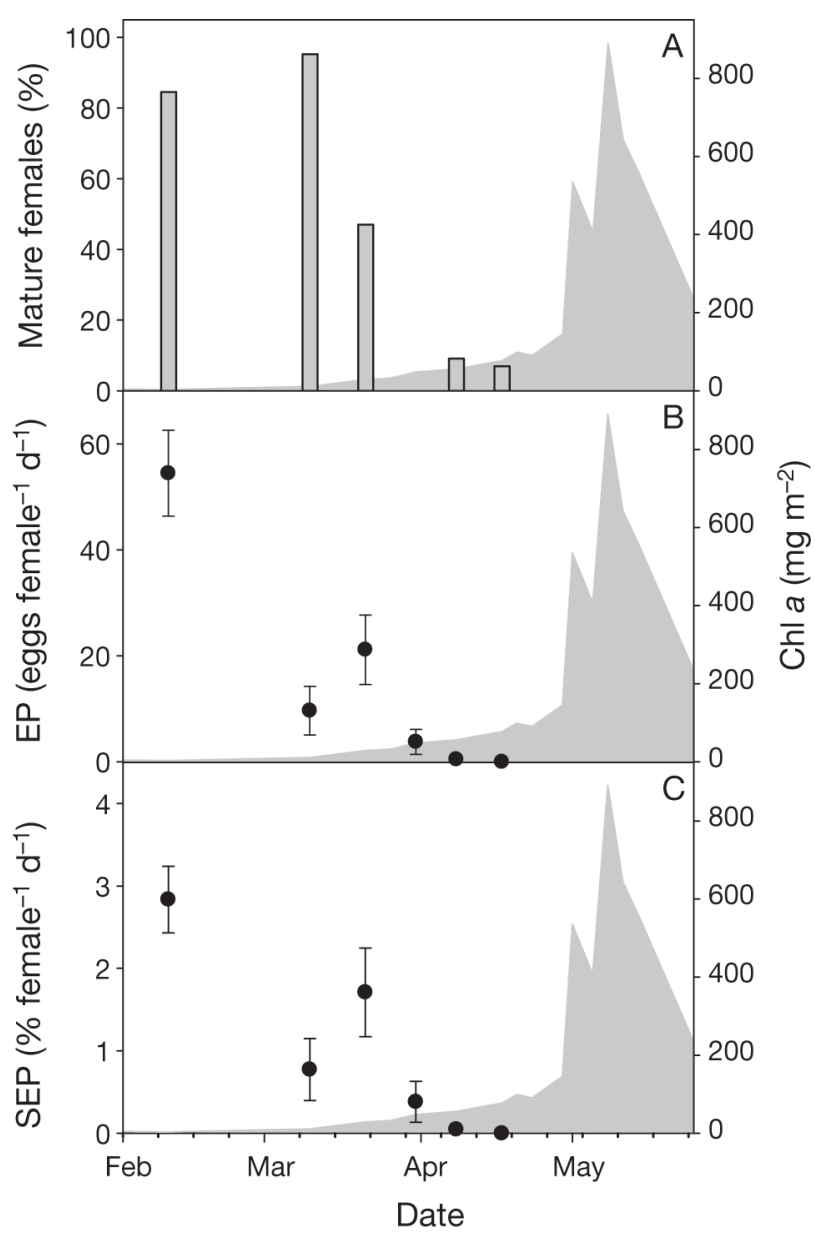

Fig. 5. Calanus hyperboreus. (A) Percentage of mature females, (B) in situ egg production (EP) $\pm \mathrm{SE}$, and (C) specific in situ egg production $(\mathrm{SEP}) \pm \mathrm{SE}$, between February and April 2009. The shaded area is integrated chlorophyll in the upper $100 \mathrm{~m}$
Pellet production as a proxy for grazing

The mean $\mathrm{SPP}_{\text {cum }}$ after 2 wk varied from 0.1 to $7.9 \%$ in the 4 groups of experiments. The separate GLMs for the pre-bloom and bloom experiments showed a strong positive effect of food for both periods (Table 4). Also, pellet production was observed in the experiment without food, and even though the intercept in the GLM (estimated value at $0^{\circ} \mathrm{C}$ without food) was not significantly positive, the mean $\mathrm{SPP}_{\text {cum }}$ after 2 wk at higher temperatures was significantly different from 0 (Table 4). The pellets produced by starved females were clear and empty 'ghost type' pellets (Seuthe et al. 2007, Kjellerup et al. 2012). There was no significant effect of temperature on $\mathrm{SPP}_{\text {cum }}$, but both coefficients were positive (with and without food, Table 4) and the temperature coefficient in a model for just the pre-bloom experiment without food was significantly positive:

$\mathrm{SPP}_{\text {cum }}=10.3 \pm 2.9(\mathrm{p}=0.038)+$
$(1.57 \pm 0.47(\mathrm{p}=0.046) \times$ temp $), \mathrm{r}^{2}=0.78$

The effects of temperature and season were also significant in a common GLM for all experiments:

$$
\begin{aligned}
\mathrm{SPP}_{\text {cum }}= & 8.9 \pm 5.1(\mathrm{p}=0.1)+ \\
& (60 \pm 4.6(\mathrm{p}<0.0001) \times \text { food })+ \\
& (1.8 \pm 0.6(\mathrm{p}=0.01) \times \text { temp })- \\
& (17.0 \pm 4.6(\mathrm{p}=0.0019) \times \text { season }), \mathrm{r}^{2}=0.92
\end{aligned}
$$

Thus, overall there was a tendency for a positive effect of temperature on $\mathrm{SPP}_{\text {cum }}$.

Fig. 7 shows a more detailed pattern for the relationship between $\mathrm{SPP}_{\text {rate, }}$ time, temperature, and food availability. For the pre-bloom experiment, there was an increase in the $\mathrm{SPP}_{\text {rate }}$ over time as $k_{2}$ was higher than $k_{1}$, whereas the opposite was observed in the
Mean SEP started at $3.5 \pm 0.5 \% \mathrm{~d}^{-1}$ and declined to $0.06 \pm 0.03 \% \mathrm{~d}^{-1}$ on 8 April until it reached 0 on 17 April. During the same period, the integrated chl a concentration down to $100 \mathrm{~m}$ increased from 3.2 to $76.9 \mathrm{mg} \mathrm{m}^{-2}$.

\section{Laboratory experiment}

Surprisingly, we observed no positive effect of temperature on either egg or fecal pellet production in the pre-bloom or bloom period. However, food had a clear positive effect on fecal pellet production, whereas there was no effect on EP (Fig. 6).
Table 3. Calanus hyperboreus. In situ reproductive values for females used to correct the measured egg production (EP) for maturity of females and to calculate specific EP rates. Maturity is the percentage of mature females (stage GS4, see 'Materials and methods') found in the upper $200 \mathrm{~m}$, and spawning frequency is the proportion of mature females that produced eggs during the $48 \mathrm{~h}$ incubation. Daily EP and clutch size are given $\pm \mathrm{SE}, \mathrm{n}$ is the number of females incubated

\begin{tabular}{|lccccc|}
\hline $\begin{array}{l}\text { Date } \\
(\mathrm{dd} / \mathrm{mm} / \text { Yy) }\end{array}$ & $\begin{array}{c}\text { Maturity } \\
\%\end{array}$ & $\begin{array}{c}\text { Spawning } \\
\text { frequency } \\
\%\end{array}$ & $\begin{array}{c}\text { Clutch size } \pm \text { SE } \\
\text { (range) } \\
\text { eggs clutch }\end{array}$ & $\begin{array}{c}\text { EP } \pm \text { SE: } \\
\text { eggs } \\
\text { female }^{-1} \mathrm{~d}^{-1}\end{array}$ & $\mathrm{n}$ \\
\hline $10 / 02 / 09$ & 85 & 95 & $134 \pm 17(17-279)$ & $64 \pm 9$ & 18 \\
$12 / 03 / 09$ & 93 & 20 & $107 \pm 19(73-148)$ & $10 \pm 5$ & 20 \\
$21 / 03 / 09$ & 47 & 50 & $165 \pm 52(40-416)$ & $45 \pm 15$ & 20 \\
$31 / 03 / 09$ & 9 & 25 & $117 \pm 67(19-203)$ & $14 \pm 8$ & 12 \\
$08 / 04 / 09$ & 7 & 33 & $30 \pm 15(9-45)$ & $5 \pm 2$ & 13 \\
$17 / 04 / 09$ & 0 & 0 & 0 & 0 & 19 \\
\hline
\end{tabular}



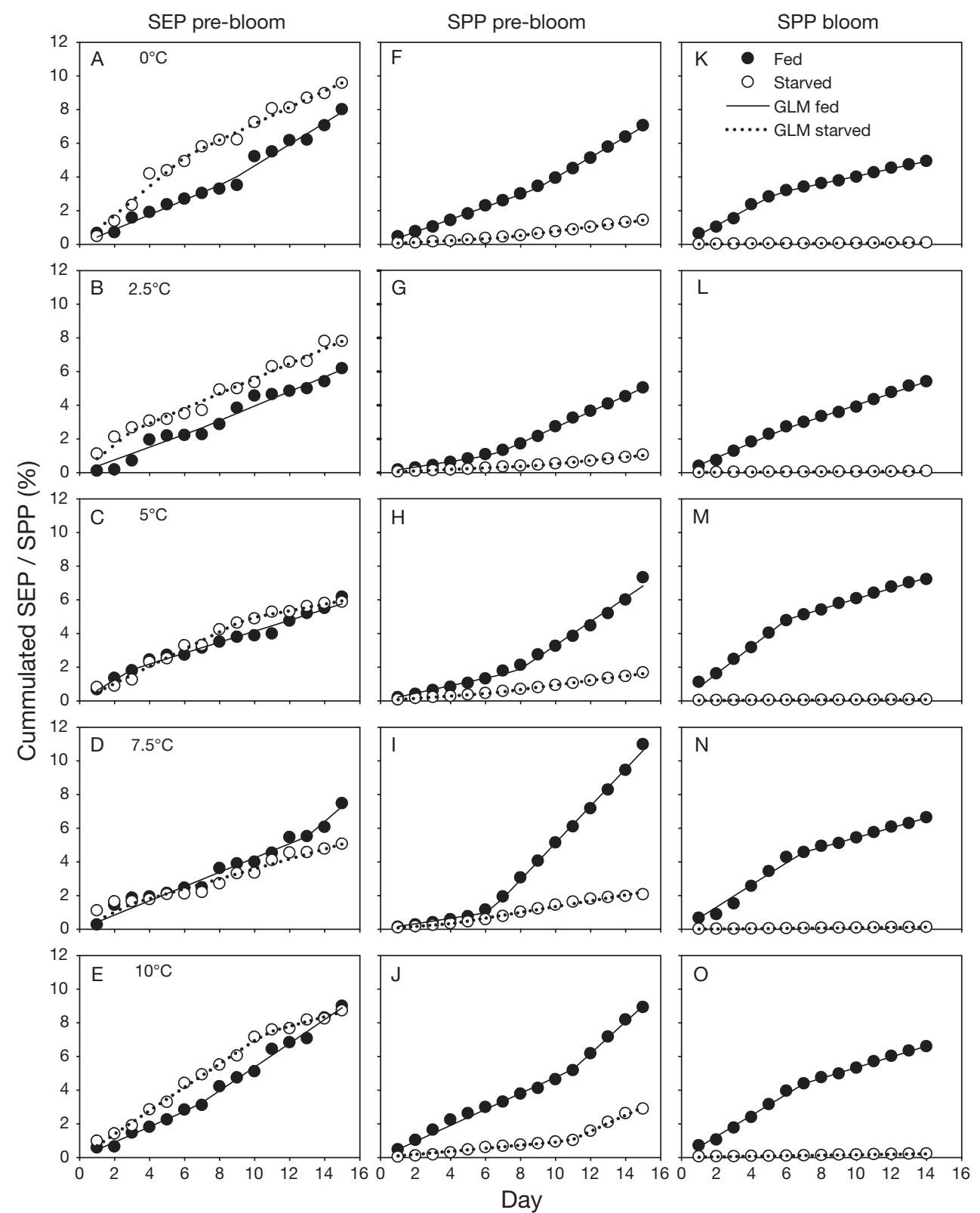

Fig. 6. Calanus hyperboreus. Cumulative specific egg production $\left(\mathrm{SEP}_{\mathrm{cum}}\right)$ and cumulative specific fecal pellet production $\left(\mathrm{SPP}_{\text {cum }}\right)$ before and during spring bloom at $0,2.5,5,7.5$, and $10^{\circ} \mathrm{C}$. Filled and empty symbols: fed and starved females, respectively. Lines: values of production predicted by the general linear model and used for estimating $k_{1}$ and $k_{2}$ (see Eq. 2 and Fig. 2 )

Table 4. Calanus hyperboreus. Cumulative specific pellet and egg production $\left(\mathrm{SPP}_{\text {cum }}\right.$ and $\left.\mathrm{SEP}_{\text {cum }}\right)$ at the end of each experiment. Intercept and coefficients for general linear models (GLM, Eq. 1) as a function of temperature and food availability are given for the 2 periods of the season. Mean values are calculated across 5 experiments at temperatures from 0 to $10^{\circ} \mathrm{C}(\mathrm{n}=5$ ).

All values given $\pm S E$; $p$-values are given in parentheses, with significant values in bold

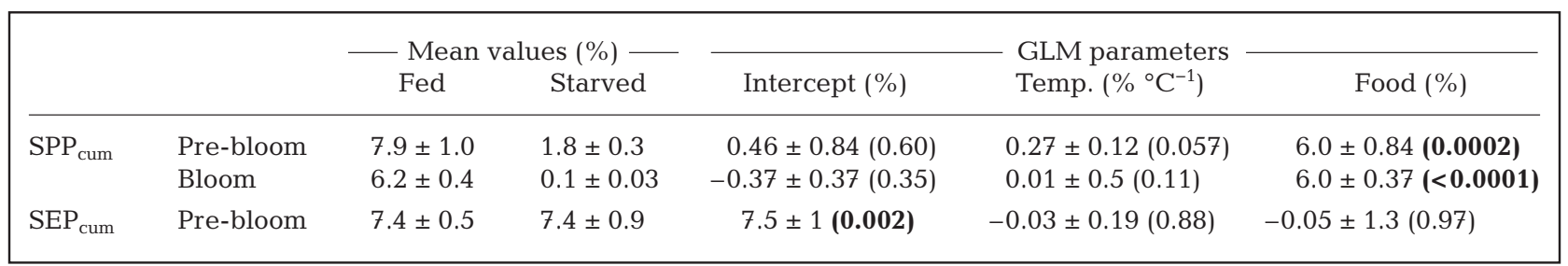



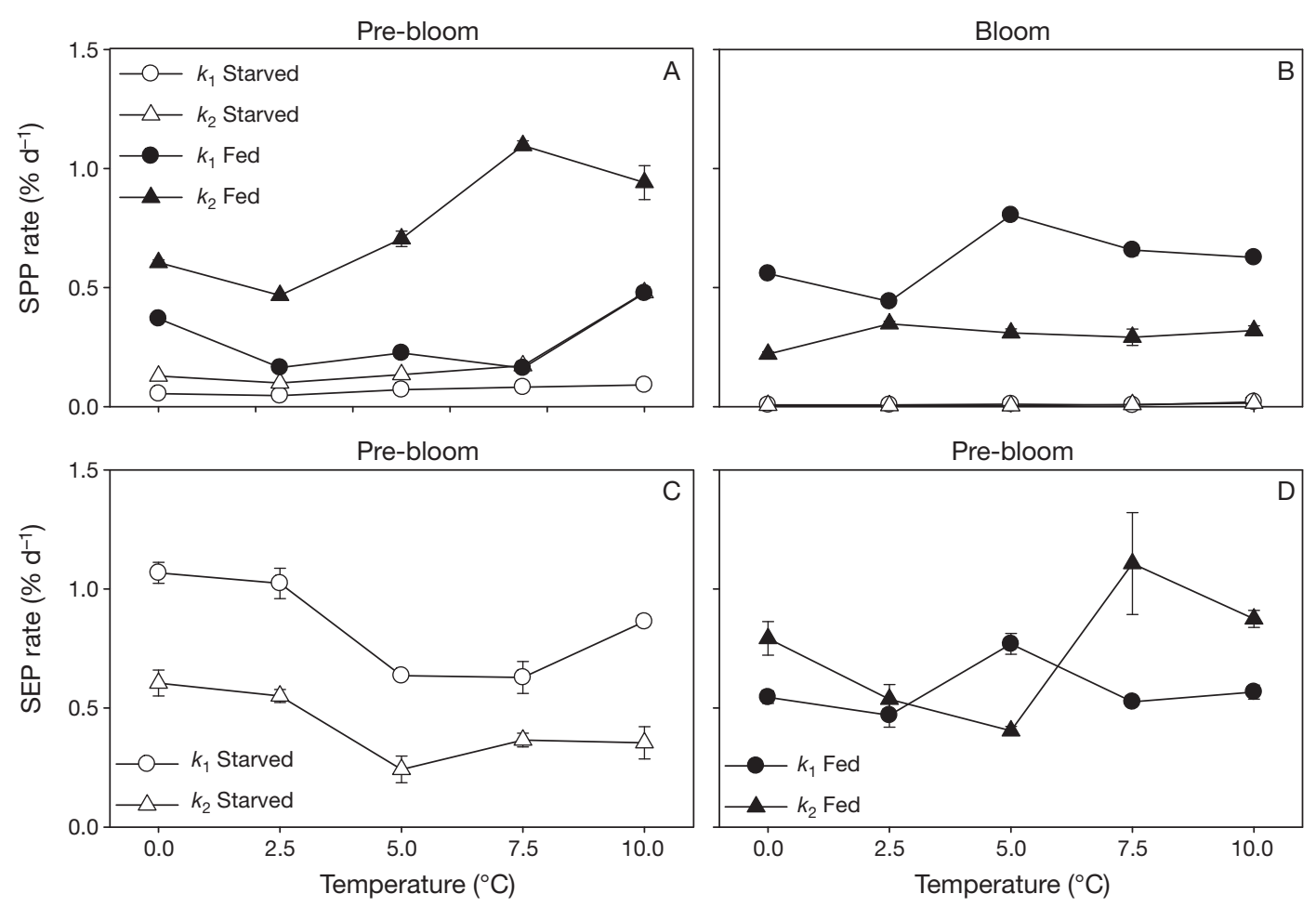

Fig. 7. Calanus hyperboreus. (A, B) Specific fecal pellet production rates $\left(\mathrm{SPP}_{\text {rate }}\right) \pm \mathrm{SE}$ before and after the bloom, and $(\mathrm{C}, \mathrm{D})$ specific egg production rates $\left(\mathrm{SEP}_{\text {rate }}\right) \pm \mathrm{SE}$ before the bloom as a function of temperature. $k_{1}\left(k_{2}\right)$ represents the first (last) part of the experiment. The filled (empty) symbols are fed (starved) females

bloom experiment with food (Fig. 7A,B). The $\mathrm{SPP}_{\text {rate }}$ in the pre-bloom experiment ranged from $0.16 \% \mathrm{~d}^{-1}$ $\left(k_{1}\right.$ at $\left.7.5^{\circ} \mathrm{C}\right)$ to $1.1 \% \mathrm{~d}^{-1}\left(k_{2}\right.$ at $\left.7.5^{\circ} \mathrm{C}\right)$ for fed females and from $0.046 \% \mathrm{~d}^{-1}\left(k_{1}\right.$ at $\left.2.5^{\circ} \mathrm{C}\right)$ to $0.48 \% \mathrm{~d}^{-1}\left(k_{2}\right.$ at $10^{\circ} \mathrm{C}$ ) for starved females. During the bloom experiment, the $\mathrm{SPP}_{\text {rate }}$ for fed females ranged from $0.2\left(k_{2}\right.$ at $\left.0^{\circ} \mathrm{C}\right)$ to $0.8 \% \mathrm{~d}^{-1}\left(k_{1}\right.$ at $\left.5^{\circ} \mathrm{C}\right)$. In the starved treatments, almost no fecal pellets were produced, thus specific values were always lower than $0.019 \% \mathrm{~d}^{-1}$ $\left(k_{1}\right.$ at $\left.10^{\circ} \mathrm{C}\right)$. Changes in $k_{1}$ and $k_{2}$ with temperature were analyzed with linear regression. The only experiment with a significant relationship between $\mathrm{SPP}_{\text {rate }}$ and temperature was the pre-bloom experiment without food. Here, the $\mathrm{SPP}_{\text {rate }}$ increased by $0.044 \pm 0.011 \%{ }^{\circ} \mathrm{C}^{-1}(\mathrm{p}=0.026)$. For all other experiments, the relationship with temperature was positive but not significant (data not presented); however, as shown in Eqs. (4) \& (5), the $\mathrm{SPP}_{\text {cum }}$ after $2 \mathrm{wk}$ was significantly positively related with temperature.

\section{Egg production}

Values for EP only exist for the pre-bloom experiment, as the females had stopped spawning at the beginning of the bloom experiment (Fig. 5). $\mathrm{SEP}_{\text {cum }}$ over 2 wk was independent of both temperature and food availability (Table 4). Although food availability had no effect on $\mathrm{SEP}_{\text {cum }}$, it had a pronounced effect on the time course of EP (Fig. $7 \mathrm{C}, \mathrm{D}$ ). In general, fed females had a lower $\mathrm{SEP}_{\text {rate }}$ at all temperatures in the first part of the experiment $\left(k_{1}\right)$ compared to starved females, whereas the rate values were reversed in the later part of the incubation $\left(k_{2}\right)$, such that after 14 to $15 \mathrm{~d}$ there was no effect of food.

SEP rates varied from 0 to $1.1 \% \mathrm{~d}^{-1}$. Maximal SEP rates were found at the lower temperatures for starved females $\left(1.07\right.$ and $1.02 \% \mathrm{~d}^{-1}, k_{1}$ at 0 and $2.5^{\circ} \mathrm{C}$, respectively) and at high temperatures for fed females $\left(1.11\right.$ and $0.87 \% \mathrm{~d}^{-1}, k_{2}$ at 7.5 and $10^{\circ} \mathrm{C}$, respectively). Nevertheless, there was no significant effect of temperature on $\mathrm{SEP}_{\text {rate }}$ for either fed or starved females (Table 4).

Carbon, nitrogen, and lipid content

Overall, Calanus hyperboreus lost carbon during the experiments (Table 5, Fig. 8). The loss was most pronounced in the pre-bloom experiment where the 
Table 5. Calanus hyperboreus. Total carbon $(\mathrm{C})$ and nitrogen $(\mathrm{N})$ content at the end of each experiment. Initial values $(\mu \mathrm{g}$ female $^{-1}$ ) represent values on Day $0(\mathrm{n}=24)$. Mean end values are followed by changes in percent of the initial value $(\Delta \%)$ across 5 experiments at temperatures from 0 to $10^{\circ} \mathrm{C}(\mathrm{n}=34$ to 36$)$. Intercept $(\%)$ and coefficients for general linear models (GLM; Eq. 1$)$ for the changes in percent of start values as a function of temperature $\left(\%{ }^{\circ} \mathrm{C}^{-1}\right)$ and food availability $(\%)$ are also given for the 2 periods of the season. All values given $\pm \mathrm{SE}_{\text {; }} \mathrm{p}$-values are given in parentheses, with significant values in bold

\begin{tabular}{|c|c|c|c|c|c|c|c|}
\hline & & \multirow{2}{*}{$\begin{array}{c}\text { Initial value } \\
\left(\mu \mathrm{g} \text { female }{ }^{-1}\right) \\
\text { In situ }\end{array}$} & \multicolumn{2}{|c|}{$\begin{array}{l}\text { Mean end values } \\
\left(\mu \mathrm{g} \text { female }{ }^{-1}, \Delta \%\right)\end{array}$} & \multirow[t]{2}{*}{ Intercept (\%) } & \multirow[t]{2}{*}{$\begin{array}{l}\text { GLM parameters } \\
\text { Temp. }\left(\%{ }^{\circ} \mathrm{C}^{-1}\right)\end{array}$} & \multirow[t]{2}{*}{ Food (\%) } \\
\hline & & & Fed & Starved & & & \\
\hline $\mathrm{C}$ & $\begin{array}{l}\text { Pre-bloom } \\
\text { Bloom }\end{array}$ & $\begin{array}{c}1692 \pm 107 \\
716 \pm 41\end{array}$ & $\begin{array}{c}1091 \pm 77,-36 \pm 5 \\
746 \pm 34,4 \pm 5\end{array}$ & $\begin{array}{r}1140 \pm 91,-33 \pm 5 \\
592 \pm 31,-17 \pm 4\end{array}$ & $\begin{array}{l}-25.8 \pm 7.0(\mathbf{( 0 . 0 0 0 5 )} \\
-14.0 \pm 6.4(\mathbf{0 . 0 3 )}\end{array}$ & $\begin{array}{l}-1.4 \pm 1.0(0.18) \\
-0.6 \pm 0.9(0.48)\end{array}$ & $\begin{array}{l}2.9 \pm 7.0(0.68) \\
21 \pm 6.4(\mathbf{0 . 0 0 1 3})\end{array}$ \\
\hline $\mathrm{N}$ & $\begin{array}{l}\text { Pre-bloom } \\
\text { bloom }\end{array}$ & $\begin{array}{l}206 \pm 11 \\
127 \pm 4\end{array}$ & $\begin{array}{l}178 \pm 8,-14 \pm 4 \\
155 \pm 5,22 \pm 4\end{array}$ & $\begin{array}{l}165 \pm 10,-20 \pm 5 \\
116 \pm 3,-8 \pm 2\end{array}$ & $\begin{array}{l}-14.2 \pm 6.2(\mathbf{0 . 0 2}) \\
-10.0 \pm 4.4(\mathbf{0 . 0 3})\end{array}$ & $\begin{array}{r}-1.1 \pm 0.9(0.20) \\
0.3 \pm 0.6(0.61)\end{array}$ & $\begin{array}{l}6.1 \pm 6.2(0.33) \\
31 \pm 4.4(<\mathbf{0 . 0 0 0 1})\end{array}$ \\
\hline
\end{tabular}

average loss for both fed and starved females after 2 wk was $34 \%$ of the initial carbon content. In the bloom experiment, the initial carbon content of the females had decreased by $58 \%$ compared to the prebloom experiment. After 2 wk of incubation, a significant difference between fed and starved treatments was observed (Table 5). Fed females were able to maintain their starting weight or even gain weight during the experiment, whereas starved females showed a net loss of $17 \%$ carbon. Food availability had a positive effect on the carbon content in the bloom experiment $(p=0.0013)$, whereas the effect was insignificant in the pre-bloom experiment $(\mathrm{p}=$ 0.68). The effect of temperature on final carbon weight was not significant in either of the 2 experiments when tested separately or when tested with a GLM across the 2 periods. There was, however, a tendency toward a negative effect of temperature of about $1 \%{ }^{\circ} \mathrm{C}^{-1}$ in both experiments (Table 5).
The overall pattern for changes in nitrogen content resembled that of carbon. There was a loss in nitrogen content at all temperatures of between 8 and $20 \%$ except for the bloom experiments with food, where the nitrogen content increased by $22 \%$. There was no effect of temperature or food on the nitrogen loss in the pre-bloom experiment, whereas in the bloom experiment there was a clear positive effect of food availability (Table 5).

Similar to the pattern described for carbon and nitrogen content, there was an overall loss of total lipids during the experimental period. The lipid loss was generally not related to either food or temperature (Table 6, Fig. 9). The lipid content of the females was analyzed in 5 groups: total lipids (TL), wax esters (WE), triacylglycerol (TAG), phospholipids (PL), and sterols (STE). As STE constituted less than $2 \%$ of TL, and no significant change during the experiments were observed, results are not included in this section.

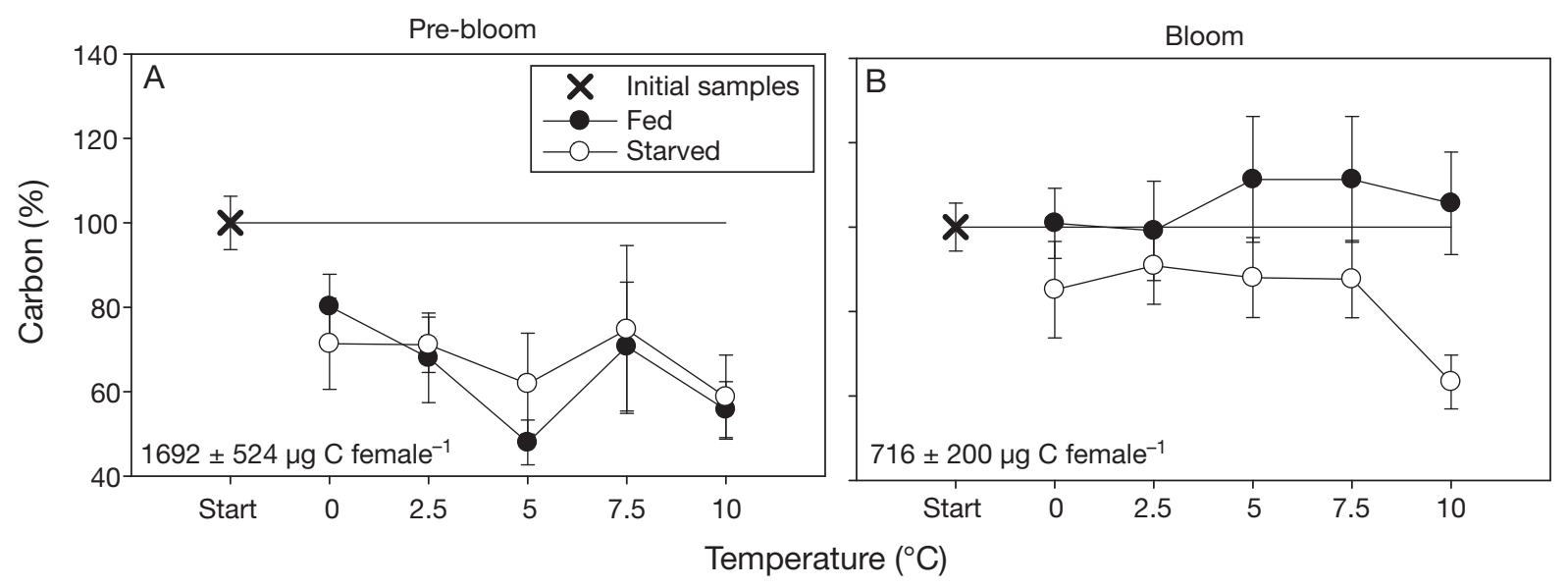

Fig. 8. Calanus hyperboreus. Carbon content at the end of the incubation period for the pre-bloom and bloom experiment at temperatures from 0 to $10^{\circ} \mathrm{C}$. Values are given in $\%$ of start content \pm SE. Filled and empty symbols: fed and starved females, respectively, the straight line represents unchanged carbon content, and the cross is the carbon value at the beginning of each experiment. The initial carbon value is given at the bottom of each panel 
Table 6. Calanus hyperboreus. Total lipids (TL), wax esters (WE), triacylglycerol (TAG), and phospholipids (PL) at the end of each experiment. Initial values ( $\mu \mathrm{g}$ female ${ }^{-1}$ ) represent values on Day $0(\mathrm{n}=15)$. Mean end values are followed by changes in percent of the initial value $(\Delta \%)$, across 5 experiments at temperatures from 0 to $10^{\circ} \mathrm{C}(\mathrm{n}=22$ to 33 ). Intercept (\%) and coefficients for general linear models (GLM; Eq. 1) for the changes in percent of start values as a function of temperature $\left({ }^{\circ} \mathrm{C}\right)$ and food availability are also given for the 2 periods of the season. All values given $\pm S E$; $p$-values are given in parentheses, with significant values in bold

\begin{tabular}{|c|c|c|c|c|c|c|c|}
\hline & & \multirow{2}{*}{$\begin{array}{c}\text { Initial value } \\
\left(\mu \mathrm{g} \text { female }^{-1}\right) \\
\text { In situ }\end{array}$} & \multicolumn{2}{|c|}{$\begin{array}{l}- \text { Mean end values }- \\
\left(\mu \mathrm{g} \text { female }{ }^{-1}, \Delta \%\right)\end{array}$} & \multirow[t]{2}{*}{ Intercept (\%) } & \multirow[t]{2}{*}{$\begin{array}{l}\text { GLM parameters } \\
\text { Temp. }\left(\%{ }^{\circ} \mathrm{C}^{-1}\right)\end{array}$} & \multirow[t]{2}{*}{ Food (\%) } \\
\hline & & & Fed & Starved & & & \\
\hline $\mathrm{TL}$ & $\begin{array}{l}\text { Pre-bloom } \\
\text { Bloom }\end{array}$ & $\begin{array}{l}997 \pm 110 \\
264 \pm 26\end{array}$ & $\begin{array}{l}606 \pm 54,-39 \pm 5 \\
230 \pm 24,-16 \pm 9\end{array}$ & $\begin{array}{l}478 \pm 59,-52 \pm 6 \\
221 \pm 29,-25 \pm 9\end{array}$ & $\begin{array}{l}-47.9 \pm 7.6(<\mathbf{0 . 0 0 0 1}) \\
-2.4 \pm 14.6(0.87)\end{array}$ & $\begin{array}{l}-1.0 \pm 1.2(0.43) \\
-2.66 \pm 2.0(0.19)\end{array}$ & $\begin{array}{c}13.6 \pm 8.4(0.11) \\
1.8 \pm 14.2(0.90)\end{array}$ \\
\hline WE & $\begin{array}{l}\text { Pre-bloom } \\
\text { Bloom }\end{array}$ & $\begin{array}{l}919 \pm 101 \\
234 \pm 25\end{array}$ & $\begin{array}{l}518 \pm 50,-44 \pm 5 \\
194 \pm 23,-21 \pm 9\end{array}$ & $\begin{array}{l}419 \pm 55,-54 \pm 6 \\
194 \pm 28,-23 \pm 10\end{array}$ & $\begin{array}{c}-50.4 \pm 7.7(\mathbf{0 . 0 0 0 1}) \\
2.02 \pm 15.6(0.90)\end{array}$ & $\begin{array}{l}-0.9 \pm 1.2(0.45) \\
-3.6 \pm 2.2(0.10)\end{array}$ & $\begin{array}{l}11.5 \pm 8.5(0.18) \\
2.5 \pm 15.2(0.85)\end{array}$ \\
\hline TAG & $\begin{array}{l}\text { Pre-bloom } \\
\text { Bloom }\end{array}$ & $\begin{array}{l}9.6 \pm 1.3 \\
9.6 \pm 0.4\end{array}$ & $\begin{array}{l}12.4 \pm 1.1,30 \pm 12 \\
2.5 \pm 0.2,-74 \pm 2.3\end{array}$ & $\begin{array}{l}9.3 \pm 1.3,-3.2 \pm 14 \\
2.1 \pm 0.2,-78 \pm 2.1\end{array}$ & $\begin{array}{l}-1.9 \pm 17.6(0.91) \\
-76.1 \pm 3.2(<\mathbf{0 . 0 0 0 1})\end{array}$ & $-0.3 \pm 2.8(0.92)$ & $\begin{array}{c}33.3 \pm 19.6(0.09) \\
3.7 \pm 3.2(0.26)\end{array}$ \\
\hline PL & $\begin{array}{l}\text { Pre-bloom } \\
\text { Bloom }\end{array}$ & $\begin{array}{l}63 \pm 8 \\
19 \pm 3\end{array}$ & $\begin{array}{l}70 \pm 5,11 \pm 8 \\
29 \pm 2.5,52 \pm 13\end{array}$ & $\begin{array}{l}47 \pm 5,-25 \pm 7 \\
19 \pm 1.7,-0.2 \pm 9\end{array}$ & $\begin{array}{l}-19.9 \pm 9.9(\mathbf{0 . 0 5}) \\
-3.1 \pm 16.4(0.85)\end{array}$ & $\begin{array}{l}-1.3 \pm 1.6(0.43) \\
-0.6 \pm 2.3(0.78)\end{array}$ & $\begin{array}{l}37.7 \pm 11.1(\mathbf{( 0 . 0 0 1 3 )} \\
52.3 \pm 16.0(\mathbf{0 . 0 0 2 6})\end{array}$ \\
\hline
\end{tabular}

However, data for STE content are available in Table 7. In the pre-bloom experiment, TL content of the females decreased by 45 to $70 \%$ in starved treatments and by 30 to $52 \%$ in fed treatments (Fig. 9, Table 7). The lipid composition was dominated by WE, which on average constituted 78 to $92 \%$ of TL in all treatments. The trend in WE therefore clearly mimicked the trend in TL (Fig. 9A,B). TAG constituted less than $3 \%$ of TL. PL constituted on average 9 to $18 \%$ of TL in all treatments. There was a clear positive effect of food on PL content, where PL increased in fed females and decreased in starved females. There was no significant effect of temperature but overall coefficients were negative (Table 6).

From pre-bloom to bloom experiment, the in situ content of lipids decreased by $74 \%$. Despite this large decrease in TL, the amount of TAG remained the same (Table 6). The lipid composition of the females at the end of each experiment was similar to what was found in the pre-bloom experiment. WE dominated with 72 to $89 \%$ of TL, followed by PL (8 to $24 \%$ ) and with TAG constituting less than $2 \%$ (Table 7 ). Again, the trend in WE mimicked the trend in TL, where no significant trend related to either temperature or food was apparent (Fig. 9E,F, Table 6). The amount of TAG decreased significantly in all treatments, ranging from 82 to $75 \%$ loss. The decrease was independent of temperature and food. The amount of PL increased for both fed and starved females at low temperatures, but at temperatures $>5^{\circ} \mathrm{C}$, PL of starved females decreased, whereas PL in fed females continued to increase to a maximum of $181 \%$ at $10^{\circ} \mathrm{C}$ (Fig. $9 \mathrm{H}$ ). As in the pre-bloom, the effect of food was highly significant, whereas the effect of temperature was not (Table 6).

\section{DISCUSSION}

\section{In situ condition}

The spring bloom in 2009 was well underway in mid-April when spawning of Calanus hyperboreus had terminated (Fig. 5). This confirms that EP in C. hyperboreus is decoupled from the phytoplankton spring bloom, which has previously been shown in Disko Bay (Madsen et al. 2001), the Greenland Sea (Hirche \& Niehoff 1996), and the Barents Sea (Melle \& Skjoldal 1998). The relative distribution of C. hyperboreus females showed that they were at overwintering depths in February and had only just started their ascent in mid-April when the chlorophyll content of the water was rising.

The in situ EP showed a maximum of 54 eggs female ${ }^{-1} \mathrm{~d}^{-1}$ in February, after which EP decreased steadily until mid-April when spawning ended. Madsen et al. (2001) measured in situ EP of Calanus hyperboreus in Disko Bay on 1 occasion in the middle of March 1997 and found EP to be $33.3 \pm 3.4$ eggs female $\mathrm{d}^{-1}$. In our study, EP in March ranged between 10 and 21 eggs female ${ }^{-1} \mathrm{~d}^{-1}$. In the Greenland Sea, a maximum production of 23 eggs female ${ }^{-1} \mathrm{~d}^{-1}$ was found in February 1988 and 1989, whereas data from November and December showed an EP as high as 148 eggs female ${ }^{-1} \mathrm{~d}^{-1}$ (Hirche \& Niehoff 1996). Generally, higher EP rates were found in November and December with values decreasing towards March. This corresponds well with what was shown in our study, viz. a clear reduction in EP as spring approached. When average female fecundity was estimated from February to April, a total number of 

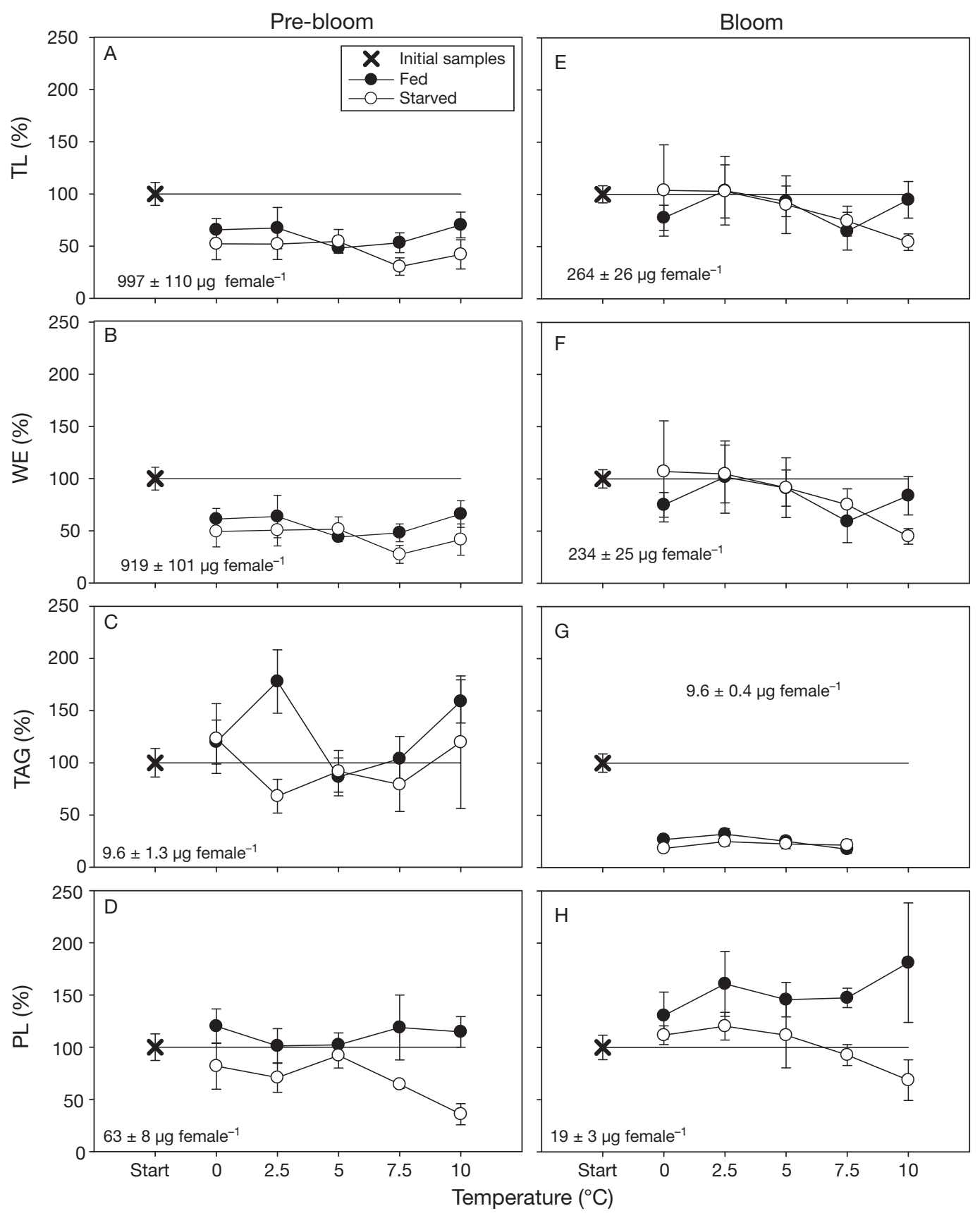

Fig. 9. Calanus hyperboreus. Total lipid (TL), wax ester (WE), triacylglycerol (TAG), and phospholipids (PL) at the end of the incubation period for the pre-bloom and bloom experiment at temperatures from 0 to $10^{\circ} \mathrm{C}$. Values are given per female as $\%$ of start content \pm SE. Filled and empty symbols: fed and starved females, respectively, the straight line represents unchanged lipid content, and the cross is the lipid value at the beginning of each experiment. The initial lipid value is given in each panel

1164 eggs female ${ }^{-1}$ was found. During the same period, a decrease in lipid content of $74 \%$ was seen. This number compares well with previous studies where female fecundity was measured in the laboratory. Conover (1967) found female EP ranging from 429 to 3397 eggs female ${ }^{-1} \mathrm{yr}^{-1}$, while other studies have observed average fecundity between 762 and
1500 eggs female ${ }^{-1}$ (Conover \& Siferd 1993, Hirche \& Niehoff 1996, Plourde et al. 2003) and a carbon loss over the same period of $81 \%$ (Plourde et al. 2003). Comparing the number of eggs laid over the spawning period with the amount of TL lost in that same period and knowing the TL content of eggs, it was calculated that $86 \%$ of the lost lipids were converted 
into eggs. However, this number leaves too little energy to cover metabolic costs. If instead a potential EP was calculated based on the lipid loss minus the energy needed for sustaining metabolism during the period (assuming a respiration rate of $0.26 \mathrm{ml} \mathrm{O}_{2} \mathrm{gDW} \mathrm{h}^{-1}$ and carbon content of $60 \%$ of DW), potential EP would be only 693 eggs female $^{-1}$, which equals $51 \%$ of the lost lipids and compares well with the assumption that $42 \%$ of an observed loss in C. hyperboreus female DW would be converted into reproductive products (Conover \& Siferd 1993).

\section{Laboratory experiments}

\section{Egg production}

The $\mathrm{SEP}_{\text {rate }}$ in the laboratory experiment showed no significant temperature or food dependence, suggesting that EP is determined by the lipid content of the female and not by environmental conditions during spawning. As a positive effect of temperature was documented for arctic Calanus glacialis in similar laboratory experiments (Kjellerup et al. 2012), it was surprising not to observe any temperature response in C. hyperboreus. Kjellerup et al. (2012) showed that $\mathrm{SEP}_{\text {rate }}$ of C. glacialis in a pre-bloom situation peaked at $7.5^{\circ} \mathrm{C}$. The SEP rate would be expected to increase with temperatures until a certain limit where high temperatures would no longer be beneficial. The results indicate that $C$. hyperboreus is a strictly Arctic species that does not benefit from higher temperatures when considering fecal pellets and EP.

A lack of response to temperature in feeding activity does not necessarily mean that Calanus hyperboreus is not 'impacted' by elevated temperature. Respiration in C. hyperboreus is lower in winter even during reproduction than in spring (Conover 1962), suggesting that animals are in 'dormancy' and optimize EP from lipid reserves. Compared with the 2 smaller Calanus spp.,

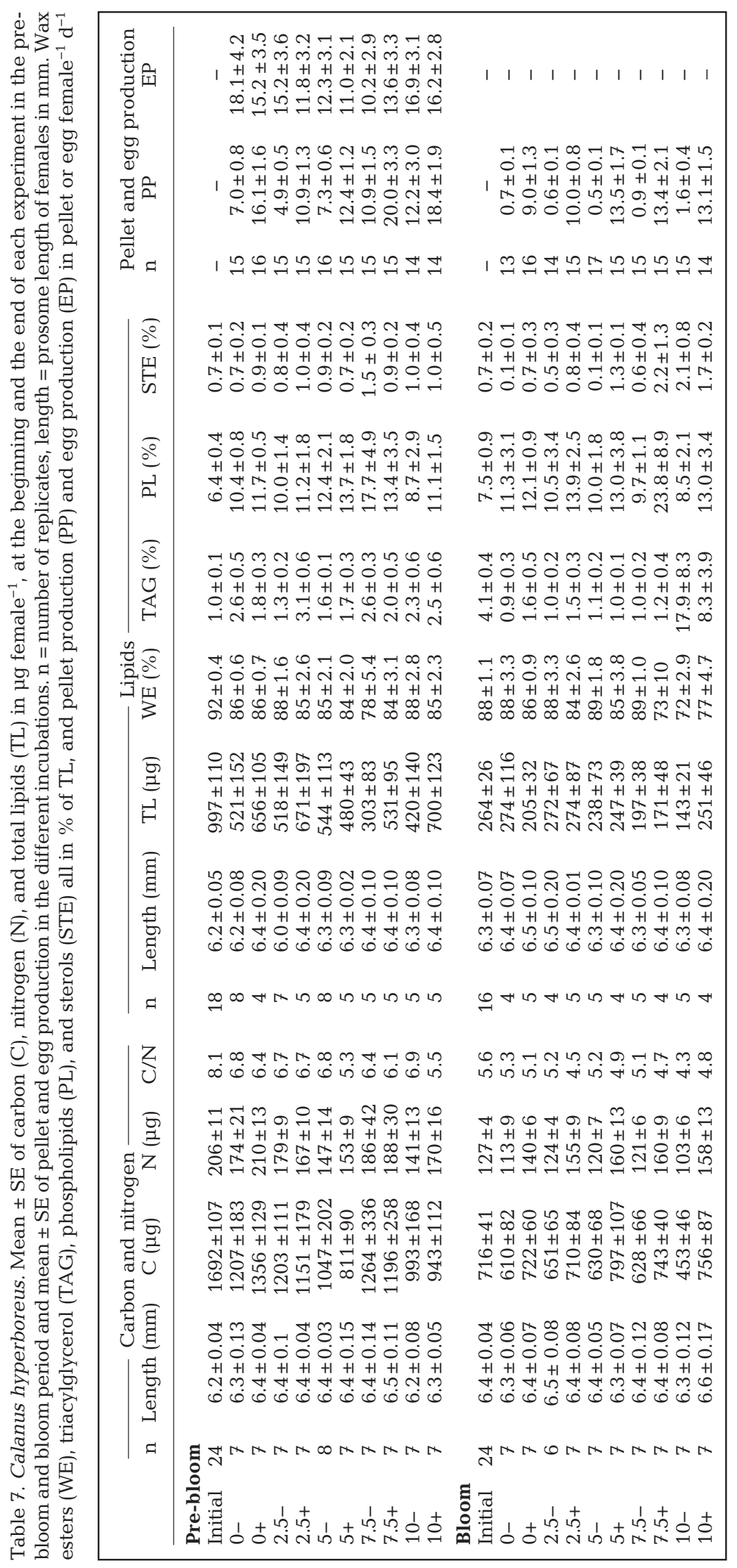


inactive or 'dormant' copepods such as C. hyperboreus could respond differently to temperature during short-term experiments, as 'dormant' animals could take a longer time to 'wake up' and adapt/react to changes in incubation conditions. Using an energy budget of EP based on long-term experiments, Plourde et al. (2003) suggested that the reproductive potential of $C$. hyperboreus would decrease between 0 and $4^{\circ} \mathrm{C}$ even with a similar daily carbon loss because of elevated respiration costs.

As Calanus hyperboreus spawns prior to the spring bloom when no food is available, the lack of a positive effect of food on EP is expected. The 2 other Calanus species in Disko Bay do not spawn until the beginning of the bloom (Madsen et al. 2001, S.J. Madsen et al. 2008) and therefore show a completely different food response. A significantly lower EP has been found in starving females for both C. glacialis and C. finmarchicus (S.J. Madsen et al. 2008, Kjellerup et al. 2012). Even though no significant effect of food was found in our study after the 2 wk period, differences in the course of production were observed, where $\mathrm{SEP}_{\text {rate }}$ increased for fed females and decreased for starved females in the last part of the experiment $\left(k_{2,}\right.$ Fig. $7 \mathrm{C}, \mathrm{D})$. Therefore, there might have been a positive effect of food if the experiment had continued for a longer time. A possible explanation for the initial lower EP of fed females is that the copepods need to adjust their metabolism to feeding, and that this takes resources away from EP. Hence, the effect of food on EP rate may depend on the pre-feeding history of the animals. This may explain the opposing results on the effects of food on EP of C. hyperboreus that have been found previously. Some studies have found EP to be independent of food (Conover 1967, Plourde et al. 2003), whereas other studies conducted later in the season have found C. hyperboreus females to produce more eggs when food was available as a supplement to internal lipids (Sømme et al. 1934, Niehoff 2007; Fig. 9). In general, EP rates measured in the laboratory experiment were lower than the in situ rates measured at the same time. As different incubation methods were used, the values found should not be compared directly. The handling method was rougher in the laboratory experiment, where a large amount of water was concentrated on a small sieve which increased the risk of breaking and disintegrating eggs. Because of the large lipid content, eggs of $C$. hyperboreus are rather fragile. Furthermore, neither of the methods prevented cannibalism of eggs, as eggs of $C$. hyperboreus are positively buoyant and hence do not sink through the sieve. Therefore, EP in this study may be underestimated. Although average
SEP in the laboratory experiments was rather low (ranging between 0.3 and $0.6 \% \mathrm{~d}^{-1}$ in the $15 \mathrm{~d}$ period), it is still comparable to what was reported in another laboratory study where SEP of $0.7 \% \mathrm{~d}^{-1}$ was measured over a 9 d period (Hirche \& Niehoff 1996).

\section{Fecal pellet production}

As expected, the fecal pellet production of fed females was significantly higher both before and during the spring bloom. In the first experiment, there seemed to be a lag phase in SPP. This could be because females were collected before the spring bloom and needed some time to reach the maximal intake of food. Consequently, the highest production was not reached before Day 6 or 7 of the experiment. The opposite tendency was observed in the second experiment, where pellet production started out high and then leveled off. The reason for this opposite tendency is unknown. Kjellerup et al. (2012) found a lag phase for both Calanus glacialis and C. finmarchicus not only before the bloom but also during the bloom. $\mathrm{SPP}_{\text {rate }}$ was higher before the spring bloom than during the bloom at all temperatures for both fed and starved females. One explanation for this decrease over the spring could be differences in assimilation efficiency related to the lifecycle of the females. In the first experiment, the females may not have been ready to feed, as they had been dwelling in deep waters where the ambient food concentration is very low. Normally they would not encounter food at this time of year, so they may not have been ready to assimilate the ingested food effectively. This might also explain the difference in food response observed between the pre-bloom and bloom experiment. Even though fed females seemed to be grazing in both periods, an effect of food on body weight was only obvious in the pre-bloom experiment (Fig. 8).

In the second experiment, the bloom was underway, and ingested food provided energy for the regeneration of gonads and lipid stores, which had been exhausted by spawning. Indeed, initial carbon and lipid content had decreased 2 and 4 times, respectively, between the 2 experiments (Figs. 8 \& 9). These stores would need to be refilled for the females to reproduce again in the following year. Furthermore, in situ investigations from Disko Bay in 2008 showed a 3.5 -fold increase in carbon content and a 4.7-fold increase in lipid content of Calanus hyperboreus females over the spring bloom, indicating such a refueling process (Swalethorp et al. 2011). As the second experiment was conducted very early in 
the bloom and only a slight increase in carbon and lipid content was observed for fed females, it is likely that the animals had just started feeding in situ and the rebuilding of lipid stores had not yet begun.

Another explanation for the lower $\mathrm{SPP}_{\text {rate }}$ in the bloom experiment could be that spent females are about to die (Head \& Harris 1985). This could also explain why $k_{2}$ was consistently lower than $k_{1}$ in the second experiment, as dying females would slowly stop all feeding. The feeding of the females in the first experiment could in such a scenario be explained by a need to attain some additional energy for EP (Takahashi et al. 2002, Niehoff 2007). Even though no effect of food on EP was seen in this experiment, the finding of a higher EP rate in the last part of the experiment for fed females makes this a likely explanation. Further studies of the fate of spawning females should be made to confirm such a hypothesis. In general, we would expect to see the same temperature dependency in pellet production as in $\mathrm{EP}$, i.e. low production at low temperatures, a temperature optimum, and a decline at temperatures that are too high. As was the case for the $\mathrm{SEP}_{\text {rater }}$ no convincing effect of temperature on $\mathrm{SPP}_{\text {rate }}$ was observed before or during the spring bloom in the temperature range investigated here.

The measured $\mathrm{SPP}_{\text {rate }}$ ranging from 0.003 to $1.1 \%$ $\mathrm{d}^{-1}$ was low compared to values obtained for Calanus finmarchicus and C. glacialis in a similarly designed experiment from 2008 where values ranged from 0.006 to $20.4 \% \mathrm{~d}^{-1}$ (Kjellerup et al. 2012) but comparable to in situ values measured for C. hyperboreus in the area during the same year, which ranged from 0.01 to $0.46 \% \mathrm{~d}^{-1}$ (Swalethorp et al. 2011). The fecal pellets produced in the starved treatments are not due to grazing but due to forced elimination of the intestinal epithelium (Besiktepe \& Dam 2002) fueled by the stored lipids as shown for the smaller Calanus species by Kjellerup et al. (2012).

\section{Carbon and lipid content over the course of the experiment}

The loss of carbon and lipids in females during the pre-bloom experiment, as well as the loss observed in situ between the pre-bloom and the bloom experiment, is partly due to the production of eggs during this period. Comparing mean lipid loss $(462 \mu \mathrm{g})$ and mean number of eggs laid (211), and knowing the lipid content of an egg $(0.54 \mu \mathrm{g}$; S. Jung-Madsen et al. unpubl.), on average $26 \%$ of the lipid lost during the incubation was channeled directly into EP.
However, this is most likely underestimated because of the underestimated EP rate (see earlier discussion). On the other hand, if assuming an EP rate equal to the in situ rate (54 eggs female ${ }^{-1} \mathrm{~d}^{-1}$ ) over the same period $(15 \mathrm{~d})$, then $96 \%$ of the lipids should have gone into reproduction, leaving too little energy to cover metabolic costs. The $26 \%$ fits better with what was calculated for the in situ situation and what was estimated by Conover \& Siferd (1993). As a consequence of the experimental design, sample sizes of lipid and carbon measurements done at the end of each experiment were quite small. The low number of animals analyzed might limit the ability to detect minor changes in biochemical composition over the relative short duration of the experiment. The variation between individuals (SE) was quite high, and higher at the termination of each experiment than at the beginning. This could be a consequence of the smaller sample size, but it might also reflect plasticity in the individual response.

\section{Temperature effects on Calanus hyperboreus}

The temperature interval of 0 to $10^{\circ} \mathrm{C}$ to which the females were exposed in this study did not reveal a temperature response in the monitored rates. Comparable studies of temperature effects on both SPP and SEP for Calanus hyperboreus are not available, although temperature-related studies investigating EP and lifecycle patterns exist. Conover (1962) investigated the respiration of $C$. hyperboreus over a range of 2 to $8^{\circ} \mathrm{C}$ and found the species to regulate their metabolism well over this interval if previously acclimatized to the temperature. Ringuette et al. (2002) found that chl a concentration and not temperature had the greatest impact on recruitment of $C$. hyperboreus copepodites, whereas they found that the recruitment of $C$. glacialis was more temperature dependent. On the other hand, Plourde et al. (2003) investigated EP at a temperature interval of 0 and $8^{\circ} \mathrm{C}$ for $\mathrm{C}$. hyperboreus and concluded that high temperatures could reduce the reproductive output of $C$. hyperboreus by $30 \%$ and shorten the spawning period significantly. Hirche (1987) studied respiration and mortality at increasing temperatures $(-0.8$ to $17^{\circ} \mathrm{C}$ ) and found C. hyperboreus to be the least temperature tolerant of the 3 Calanus species.

Both Calanus glacialis and C. finmarchicus show a positive response to higher temperatures in terms of pellet production and EP rates (Kjellerup et al. 2012). Thus, the finding that $C$. hyperboreus shows no temperature response suggests potential future changes 
in composition of the Calanus community in Disko Bay. In a warmer climate, the fact that $C$. finmarchicus has a clear advantage of temperatures up to at least $10^{\circ} \mathrm{C}$ while C. glacialis increases production rates up to $7.5^{\circ} \mathrm{C}$ could give these 2 species a competitive advantage over C. hyperboreus.

Other opposing and more indirect effects of a warmer climate will also influence the future biomass composition. Ringuette et al. (2002) suggested that a longer productive season in the Arctic as a consequence of a warmer climate could result in earlier recruitment of Calanus glacialis and C. hyperboreus and a possibility for them to complete their lifecycles faster and thereby increase their population sizes. However, Plourde et al. (2003) showed that a warmer climate would lead to a shorter winter-spawning season for $C$. hyperboreus and a subsequent mismatch between the development from egg to the first feeding nauplii stage and the spring bloom which could lead to a decrease in population size. Because a temperature increase will impact developmental stages and phases of Calanus spp. life cycles differently, it is difficult to predict exactly how the composition of the Calanus community will change with increasing temperature in the future. A warmer climate may also change the relative composition of the copepod community in general, with replacement of the arctic species adapted to sea ice by subarctic and boreal generalist species (Darnis et al. 2008)

In conclusion, this study demonstrates the winterspawning strategy of Calanus hyperboreus in which reproduction is coupled to the spring bloom with a time lag of 1 yr. Furthermore, it was documented that temperature had no positive effect on either egg or pellet production of $C$. hyperboreus. This finding suggests that this high-energy Calanus species will lose in competition with the 2 smaller Calanus species in a future warmer climate because of the ability of the smaller species to exploit the higher temperature to increase their grazing and EP rates (Kjellerup et al. 2012). However, to fully elucidate the changes in the future Calanus community, the growth response of the smaller non-reproductive stages have to be investigated and considered.

Acknowledgements. This study was supported by ECOGREEN, the WWF/Novozymes research grant and the European Union Seventh Framework Programme project EUROBASIN (ENV.2010.2.2.1-1) under grant agreement no. 264933. Thanks to M.O. Hansen, scientific leader at Arctic Station Copenhagen University, and the crew of RV 'Porsild' for help during the work in Greenland, and A. Busk Faaborg, R. Guttesen, and R. Swalethorp for help in the laboratory at Roskilde University.

\section{LITERATURE CITED}

ACIA (Arctic Climate Impact Assessment) (2004) Impacts of a warming Arctic: synthesis report of the Arctic climate impact assessment. Policy document prepared by the Arctic Council and presented at the Fourth Arctic Council Ministerial Meeting, Reykjavik. Cambridge University Press, Cambridge

> Auel H, Klages M, Werner I (2003) Respiration and lipid content of the Arctic copepod Calanus hyperboreus overwintering $1 \mathrm{~m}$ above the seafloor at 2,300 $\mathrm{m}$ water depth in the Fram Strait. Mar Biol 143:275-282

Båmstedt U (1986) Chemical composition and energy content. In: Corner EDS, O'Hara S (eds) Biological chemistry of marine copepods. University Press, Oxford, p 1-58

Besiktepe S, Dam HG (2002) Coupling of ingestion and defecation as a function of diet in the calanoid copepod Acartia tonsa. Mar Ecol Prog Ser 229:151-164

Conover RJ (1962) Metabolism and growth in Calanus hyperboreus in relation to its life cycle. Rapp P-V Réun Cons Perm Int Explor Mer 153:190-197

Conover RJ (1964) Food relations and nutrition of zooplankton. In: Proc Symp Exp Mar Biol Ecol. Occas Publ Univ R I 2:81-91

> Conover RJ (1967) Reproductive cycle, early development, and fecundity in laboratory populations of the copepod Calanus hyperboreus. Crustaceana 13:61-72

> Conover RJ (1988) Comparative life histories in the genera Calanus and Neocalanus in high latitudes of the northern hemisphere. Hydrobiologia 167-168:127-142

Conover RJ, Siferd TD (1993) Dark-season survival strategies of coastal zone zooplankton in the Canadian Arctic. Arctic 46:303-311

Darnis G, Barber DG, Fortier L (2008) Sea ice and the onshore-offshore gradient in pre-winter zooplankton assemblages in southeastern Beaufort Sea. J Mar Syst 74: 994-1011

> Dünweber M, Swalethorp R, Kjellerup S, Nielsen TG and others (2010) Succession and fate of the spring diatom bloom in Disko Bay, western Greenland. Mar Ecol Prog Ser 419:11-29

Falk-Petersen S, Mayzaud P, Kattner G, Sargent JR (2009) Lipids and life strategy of Arctic Calanus. Mar Biol Res 5: 18-39

> Hansen AS, Nielsen TG, Levinsen H, Madsen SD, Thingstad TF, Hansen BW (2003) Impact of changing ice cover on pelagic productivity and food web structure in Disko Bay, West Greenland: a dynamic model approach. DeepSea Res I 50:171-187

Hansen BU, Elberling B, Humlum O, Nielsen N (2006) Meteorological trends (1991-2004) at Arctic Station, Central West Greenland $\left(69^{\circ} 15^{\prime} \mathrm{N}\right)$ in a 130 years perspective. Dan J Geogr 106:45-55

Hansen MO, Nielsen TG, Stedmon C, Munk P (in press) Oceanographic regime shift during 1997 in Disko Bay, Western Greenland. Limnol Oceanogr

Hansen PJ (1989) The red tide dinoflagellate Alexandrium tamarense: effect on behaviour and growth of a tintinnid ciliate. Mar Ecol Prog Ser 53:105-116

> Head EJH, Harris LR (1985) Physiological and biochemical changes in Calanus hyperboreus from Jones Sound NWT during the transition from summer feeding to overwintering conditions. Polar Biol 4:99-106

Heide-Jørgensen MP, Acquarone M (2002) Size and trends of the bowhead, beluga and narwhal stocks wintering off 
West Greenland. Sci Publ N Atl Mar Mamm Comm 4: 191-210

- Hirche HJ (1987) Temperature and plankton. II. Effect on respiration and swimming activity in copepods from the Greenland Sea. Mar Biol 94:347-356

Hirche HJ, Kwasniewski S (1997) Distribution, reproduction and development of Calanus species in the Northeast water in relation to environmental conditions. J Mar Syst 10:299-317

> Hirche HJ, Niehoff B (1996) Reproduction of the Arctic copepod Calanus hyperboreus in the Greenland Seafield and laboratory observations. Polar Biol 16:209-219

Holland DM, Thomas RH, De Young B, Ribergaard MH, Lyberth B (2008) Acceleration of Jakobshavn Isbræ triggered by warm subsurface ocean waters. Nat Geosci 1: 659-664

Ikeda T, Torres JJ, Hernandez-Leon S, Geiger SP (2000) Metabolism. In: Harris R, Wiebe P, Lenz J, Skjoldal HR, Huntley $M$ (eds) ICES zooplankton methodology manual. Academic Press, London, p 455-532

Jespersen AM, Christoffersen K (1987) Measurements of chlorophyll a from phytoplankton using ethanol as extraction solvent. Arch Hydrobiol 109:445-454

Karnovsky NJ, Kwaśniewski S, Wesławski JM, Walkusz W, Beszczyńska-Möller A (2003) Foraging behavior of little auks in a heterogeneous environment. Mar Ecol Prog Ser 253:289-303

Kjellerup S, Dünweber M, Swalethorp R, Nielsen TG, Møller EF, Markager S, Hansen BW (2012) Effects of a future warmer ocean on the coexisting copepods Calanus finmarchicus and C. glacialis in Disko Bay, western Greenland. Mar Ecol Prog Ser 447:87-108

> Lee RF, Hagen W, Kattner G (2006) Lipid storage in marine zooplankton. Mar Ecol Prog Ser 307:273-306

> Madsen SD, Nielsen TG, Hansen BW (2001) Annual population development and production by Calanus finmarchicus, C. glacialis and C. hyperboreus in Disko Bay, western Greenland. Mar Biol 139:75-93

Madsen SD, Nielsen TG, Hansen BW (2008) Annual population development and production by small copepods in Disko Bay, western Greenland. Mar Biol 155:63-77

Madsen SJ, Nielsen TG, Tervo OM, Söderkvist J (2008) Importance of feeding for egg production in Calanus finmarchicus and C. glacialis during the Arctic spring. Mar Ecol Prog Ser 353:177-190

Melle W, Skjoldal HR (1998) Reproduction and development of Calanus finmarchicus, C. glacialis and C. hyperboreus in the Barents Sea. Mar Ecol Prog Ser 169:211-228

Motyka RJ, Truffer M, Fahnestock M, Mortensen J, Rysgaard S, Howat I (2011) Submarine melting of the 1985 Jakobshavn Isbræ floating tongue and the triggering of the current retreat. J Geophys Res 116:F01007. doi: 10.1029/2009JF001632

Niehoff B (2007) Life history strategies in zooplankton communities: the significance of female gonad morphology and maturation types for the reproductive biology of marine calanoid copepods. Prog Oceanogr 74:1-47

Niehoff B, Hirche HJ (1996) Oogenesis and gonad matura-

Editorial responsibility: Marsh Youngbluth,

Fort Pierce, Florida, USA tion in the copepod Calanus finmarchicus and the prediction of egg production from preserved samples. Polar Biol 16:601-612

Niehoff B, Runge JA (2003) A revised methodology for prediction of egg production of the marine planktonic copepod Calanus finmarchicus from preserved samples. J Plankton Res 25:1581-1587

> Nielsen TG, Hansen B (1995) Plankton community structure and carbon cycling on the western coast of Greenland during and after the sedimentation of a diatom bloom. Mar Ecol Prog Ser 125:239-257

> Omori M (1969) Weight and chemical composition of some important oceanic zooplankton in the North Pacific Ocean. Mar Biol 3:4-10

> Pasternak A, Arashkevich E, Tande K, Falkenhaug T (2001) Seasonal changes in feeding, gonad development and lipid stores in Calanus finmarchicus and C. hyperboreus from Malangen, northern Norway. Mar Biol 138: 1141-1152

> Plourde S, Joly P, Runge JA, Dodson J, Zakardjian B (2003) Life cycle of Calanus hyperboreus in the lower St. Lawrence Estuary and its relationship to local environmental conditions. Mar Ecol Prog Ser 255:219-233

Reigstad M, Riser CW, Svensen C (2005) Fate of copepod faecal pellets and the role of Oithona spp. Mar Ecol Prog Ser 304:265-270

> Ringuette M, Fortier L, Fortier M, Runge JA and others (2002) Advanced recruitment and accelerated population development in Arctic calanoid copepods of the North Water. Deep-Sea Res II 49:5081-5099

Scott CL, Kwasniewski S, Falk-Petersen S, Sargent JR (2000) Lipids and life strategies of Calanus finmarchicus, Calanus glacialis and Calanus hyperboreus in late autumn, Kongsfjorden, Svalbard. Polar Biol 23:510-516

Seuthe L, Darnis G, Riser C, Wassmann P, Fortier L (2007) Winter-spring feeding and metabolism of Arctic copepods: insights from faecal pellet production and respiration measurements in the southeastern Beaufort Sea. Polar Biol 30:427-436

Slagstad D, Ellingsen IH, Wassmann P (2011) Evaluating primary and secondary production in an Arctic Ocean void of summer sea ice: an experimental simulation approach. Prog Oceanogr 90:117-131

Sømme JD (1934) Animal plankton of the Norwegian Coast Waters and the open Sea. Fiskeridir Skr Ser Havunders 4:7-161

Søreide JE, Falk-Petersen S, Hegseth EN, Hop H, Carroll ML (2008) Seasonal feeding strategies of Calanus in the highArctic Svalbard region. Deep-Sea Res II 55:2225-2244

> Swalethorp R, Kjellerup S, Dünweber M, Nielsen TG, Møller EF, Rysgaard S, Hansen BW (2011) Production of Calanus finmarchicus, C. glacialis and C. hyperboreus in Disko Bay, Western Greenland, with emphasis on life strategy. Mar Ecol Prog Ser 429:125-144

Takahashi K, Nagao N, Taguchi S (2002) Respiration of adult female Calanus hyperboreus (Copepoda) during spring in the North Water Polynya. Polar Biosci 15: 45-51

Submitted: January 5, 2011; Accepted: September 27, 2011 Proofs received from author(s): February 6, 2012 